\title{
COMMENTS
}

\section{SPEAKING TRUTH TO POWER: INTELLIGENCE OVERSIGHT IN AN IMPERFECT WORLD}

\section{David Everett Colton $\dagger$}

Since the United States assumed global responsibilities following the two World Wars of this century, the nation has continually struggled to reconcile geopolitical responsibilities with its liberal democratic values. ${ }^{1}$ One microcosm of this struggle is the structural challenge of integrating secrecy and democracy. ${ }^{2}$ The Iran-Contra episode, ${ }^{3}$ and

† B.A. 1984, University of Pennsylvania; M.A. 1988, Johns Hopkins School of Advanced International Studies; J.D. Candidate 1989, University of Pennsylvania.

1 See R. Osgood, Ideals and Self-INTEREST IN AMERICA'S Foreign Relations: The Great Transformation of the Twentieth Century 437, 439 (1953) (noting that the "wise conduct of foreign relations must involve a continual series of compromises with perfection," but "America's problem of reconciling its ideals with its self-interest comes close to being a life-or-death matter"); see also INTELLIgence: Policy AND Process 6 (A. Maurer, M. Tunstall \& J. Keagle eds. 1985) [hereinafter Policy AND Process] ("Do Americans, like Hegel, believe that reason of state is reason enough or, like Machiavelli, that the state should at least appear to act in accord with high moral standards?"). This intellectual confusion has a direct impact on perceptions about the role and utility of intelligence capabilities in American foreign policy. As an example of one naive but not uncommon view, a Senate Committee investigating the CIA in the mid-1970s suggested that "traditional notions of fair play" should guide American international behavior. See Senate Select Commitree ro STUdy GOVERNMENTAL Operations WITH RESPECT TO INTELligenCE, INTERIM REPORT, 94th Cong., 2d Sess. 258-59 (1976).

2 For a distinctly idiosyncratic interpretation of the American experience, see S. Turner, Secrecy and Democracy: The CIA in Transition 278-85 (1985) (arguing that the tensions that arise when a democracy engages in secret intelligence operations require more openness and the application of "just war" theory to intelligence). But see Lockhart, Intelligence: $A$ British View, in BRITISH AND AMERICAN APPROACHES TO INTELLIGENCE 37, 46 (K. Robertson ed. 1987) [hereinafter APPROACHES TO INTELLIGENCE] ("The essential skill of a secret intelligence service is to get things done secretly and deniably."). For a comparative discussion of secret activities and Western democratic systems, see Godson, Intelligence: An American View: The Uses and Limits of Intelligence, in APPROACHES TO INTELLIGENCE, supra, at 5-11. See also W. LAqueUR, A WORLD OF SECRETS 201-32 (1985) (describing the establishments in various Western states).

3 See House Select Comm. to Investigate Covert arms Transactions 
earlier controversies such as the mining of Nicaraguan harbors ${ }^{4}$ and paramilitary support for the anti-communist forces in Nicaragua ${ }^{5}$ are recent examples of this long simmering struggle. Allegations of intelligence agency abuses were brought to the attention of the general public in the early $1970 \mathrm{~s}^{6}$ Since then, a stable solution to the conflict has

With Iran and Senate Select Comm. ON Secret Military Assistance to Iran

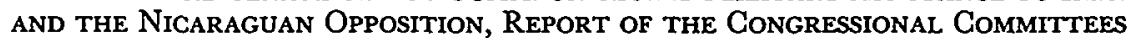
Investigating the Iran-Contra Affair, S. Rep. No. 216, H.R. Rep. No. 433, 100th Cong., 1st Sess. (1987) [hereinafter IRAN-ConTra REPORT] (detailing the Reagan Administration's use of secret arms sales to Iran as a means of funding covert assistance to anti-communist forces in Central America).

4 See, e.g., CIA Views Minelaying Part of Covert "Holding Action," Wash. Post, Apr. 10, 1984, at 1, col. 3 (describing congressional leaders' reaction to CIA mining of Nicaraguan ports); see also infra notes 63-65 (describing the reasons the Senate intelligence committee was not aware of the mining).

- See IRAN-Contra REPORT, supra note 3, at 25-150, 501-16. The administration's "secret" support for the anti-communist forces in Nicaragua was well known long before the government dropped its pretense that the support was "covert." See, e.g., America's Secret Warriors, NewsweEk, Oct. 10, 1983, at 38, 39 (describing U.S. "covert" assistance to the Nicaragua rebels). This part of what former CIA General Counsel Daniel Silver called "the spectacle of overt covert actions". See Silver, The Uses and Misuses of Intelligence Oversight, 11 Hous. J. INT'L L. 7, 10 (1988). Another example of this spectacle would be U.S. assistance to the Afghan resistance.

In 1983, upset over the administration's covert policies in Central America, the House Intelligence Committee held hearings on a bill that would have required congressional authorization for "any clandestine paramilitary or military activity." See Congressional Oversight of Covert Activities: Hearings Before the House Permanent Select Comm. on Intelligence, 98th Cong., 1st Sess. 4 (1983) (statement of Wyche Fowler, Chairman, Subcomm. on Oversight and Evaluation). The first Boland Amendment, passed in FY 1983, prohibited the CIA, Pentagon, State Department, and any other intelligence agency or its assets from furnishing military equipment, training, advice, or other military support to paramilitary groups whose goal was to overthrow the Sandinista regime, or to provoke a military exchange between Honduras and Nicaragua. See Further Continuing Appropriations Act of 1983, Pub. L. No. 97-377, $\S 793,96$ Stat. 1830,1865 (1982). For a complete analysis of the various guises of the Boland Amendment from FY 1983-87, see IRAN-ConTRA REPORT, supra note 3, at 395-407, 489-99.

- For example, in 1974, the New York Times featured stories by Seymour Hersh alleging CIA complicity in the overthrow of Chilean President Salvador Allende and surveillance of anti-war protestors in the United States. See, e.g., Underground for the C.I.A. in New York: An Ex-Agent tells of Spying on Students, N.Y. Times, Dec. 29, 1974, at A1, col. 1 (alleging CIA surveillance of antiwar protestors); Helms Disavows "Illegal" Spying by the CIA in U.S., N.Y. Times, Dec. 25, 1974, at A1, col. 8 (same); Huge CIA Operation Reported in U.S. Against Antiwar Forces, Other Dissidents in Nixon Years, N.Y. Times, Dec. 22, 1974, at A1, col. 8 (same); Kissinger Chile Briefings Said to Omit Mention of C.I.A. Link to Labor Unrest, N.Y. Times, Sept. 21, 1974, at A12, col. 3 (alleging CIA involvement in Allende's demise); C.I.A. Chief Tells House of \$8-Million Campaign Against Allende in '70-73, N.Y. Times, Sept. 8, 1974, at A1, col. 7 (same); see also Domestic Spying Denied: Helms Rejects Charges Made Against CIA, Wash. Post, Dec. 25, 1974, at A1, cols. 6 \& 8 (alleging CIA surveillance of antiwar protestors). These reports were in fact only partially accurate, but they nonetheless contributed to the impression of the CIA as a rogue agency. See Commission on GIA Activities Within the U.S., Report to THE President 130-50 (1975) (stating that "Operation CHAOS," the domestic surveillance operation, 
eluded three administrations ${ }^{7}$, three special congressional committees, ${ }^{8}$ and two blue-ribbon presidential panels. ${ }^{9}$

As a result, Congress's relationship with the Executive has been marked with wariness in the area of intelligence. ${ }^{10}$ Policy differences

was carried out reluctantly by the CIA at the urging of the Johnson and Nixon administrations); T. POWERs, The MAN Who Kept the Secrets: Richard Helms \& THE CIA 220-31 (1979) (stating that the GIA became involved in Chile at Nixon's insistence despite Director Helms' objections); B. WoodWARd, VeIL: The SEcreT WARS OF THE CIA 1981-1987 at 56 (1987) (same).

7 President Ford was the first president to issue an executive order clarifying and delimiting the intelligence community's scope of operations. See Exec. Order No. 11,905, 41 Fed. Reg. 7703 (1976) [hereinafter Ford Exec. Order 11,905]. Ford's order, clearly a reaction to congressional and media criticisms of domestic intelligence activities, also contained the first written language prohibiting "political assassination." See id. at 31,41 Fed. Reg. at 7733.

Presidents Carter and Reagan also issued executive orders regarding the intelligence community. President Carter's order focused on restrictions and oversight concerns. See Exec. Order No. 12,036, 43 Fed. Reg. 3674 (1978) [hereinafter Carter Exec. Order 12,036]. President Reagan's order, however, took a different approach. While mandating compliance with existing law, it demanded performance from the intelligence community, seeking to re-instill some élan to a bureaucracy still retreating from public criticism. See Exec. Order No. 12,333, 3 C.F.R. 200 (1981) [hereinafter Reagan Exec. Order 12,333]; J. Oseth, Regulating U.S. Intelligence Operations: A Study in Definition of the National INTERest 42-70 (1985)(surveying the public critique of intelligence operations); see also B. WoODWARD, supra note 6, at 55 (quoting a prominent Washington attorney as saying to DCI William Casey, "The GIA is like a great dog that got hit by a truck. You can only say, 'He was a great dog until he got hit by a truck." ").

8 In 1974, the Senate created the Church Committee to investigate allegations of abuses committed by intelligence agencies. See S. Res. 21, 94th Cong., 1st Sess., 121 Cong. Rec. 1416 (1975). The Church Committee, with a staff at one point reaching 130 professionals, consultants, and clerks, spent $\$ 3$ million and over 15 months investigating the intelligence community. See Goldwater, Congress and Intelligence Oversight, WASH. Q., Summer 1983, at 16 ("I wish we could try to do to the Soviet KGB what we tried to do to ourselves.").

The House created a parallel committee, known as the Pike Committee, which was even more controversial than the Church Committee. Chairman Otis Pike's position that "[t]he bottom line is that Congress has the right to receive classified information without strings attached to it" led to numerous confrontations with both the House leadership and the Executive. See L. Johnson, A SEAson of InQuiry: The Senate INTELLIGENCE INVESTIGATION 78-79 (1985). A joint select committee to investigate the Iran-Contra incident was created in 1987. See H.R. Res. 12, 100th Cong., 1st Sess. (1987); S. Res. 23, 100th Cong., 1st Sess. (1987).

- See Exec. Order No. 11,828, 3 G.F.R. 933 (1975) (creating the Rockefeller Commission to investigate the alleged domestic activities of the CIA); see also PrEsIden'T's Special Review Board, Report of the President's Special Review BOARD at I1-I3 (1987) [hereinafter TowER CoMmIssion] (investigating the National Security Council and the circumstances and events of the Iran-Contra incident).

${ }^{10}$ The debate over intelligence has its roots in the maelstrom of changing executive and legislative distributions of power in the aftermath of Vietnam and Watergate. In addition to the substantive areas for disagreement between the branches, Congress was in the midst of a structural revolution that posed great problems for relations with executive branch intelligence organizations. See, e.g., D. PRICE, BRINGING BACK THE PARTIEs 56 (1984) (noting the general transition in Congress from a power broker 
between Congress and the Reagan Administration served to increase this mistrust, ${ }^{11}$ and in the aftermath of the Iran-Gontra incident, have led to the introduction of numerous intelligence "reform" proposals. ${ }^{12}$

Our national commitment to intelligence oversight is unique; no other nation has sought to balance the imperatives of national security with democratic values in so public a fashion ${ }^{13}$ and thereby risked los-

status of hierarchical congressional organization to a "bargaining" system in which authority was more diffuse); S. SMITH \& C. DeERING, CommitTeEs IN Congress 20-31 (1984) (describing the earlier structure of congressional organization and the impact of the changing committee systems); J. SunDQUIST, The Decline and ResurgenCE of CoNGress 272-343 (1981) (noting that congressional attempts to regain control of foreign policy and its use of the oversight mechanism to enforce its will). This changing environment had an obvious impact on the intelligence community. See generally $\mathrm{L}$. JoHNSON, supra note 8 (describing the congressional investigations of the intelligence community in the mid-1970s and the difference in attitudes between the new authority structure and the old power broker system).

11 See IrAN-ConTra REPORT, supra note 3, at 19-20; see also B. WoodWARD, supra note 6, at 322 (quoting Chairman of the Senate Select Committee on Intelligence Barry Goldwater's letter to DCI Director William Casey after the Nicaraguan mining: "I am pissed off!"). The tension characterizing congressional-executive relations in the 1980s led to disturbing trends in oversight. Frequent charges were made by Congress that the intelligence on Central America was politicized and nonobjective, and in the eyes of many observers, the attitudes of congressional oversight committees assumed an increasingly partisan tone. See A.B.A. Standing Comm. ON Law and Nat'l SecurITY, OVERSIGHT AND ACCOUNTABILITY OF THE U.S. INTELLIGENCE AGENCIES: AN Evaluation 21 (1985) [hereinafter ABA Evaluation].

12 See, e.g., S. 1852, 100th Cong., 1st Sess. (1987) ("Intelligence Activities Oversight Improvement Act"); S. 1820, 100th Cong., 1st Sess. (1987) ("National Intelligence Reorganization Act of 1987"); S. 1818, 100th Cong., 1st Sess. (1987) ("National Security Reform Act of 1987"); S. 1721, 100th Cong., 1st Sess. (1987) ("Intelligence Oversight Act of 1987"); S. 1458, 100th Cong., 1st Sess. (1987) ("GAO-CIA Audit Act of 1987"); S. 1235, 100th Cong., 1st Sess. (1987) (amending National Security Act of 1947 to provide that Director of Central Intelligence will serve a seven-year term); H.R. 3822, 100th Cong., 1st. Sess. (1987) ("Intelligence Oversight Act of 1987"); H.R. 1013, 100th Cong., 1st Sess. (1987) ("Intelligence Oversight Amendments of 1987"); see also infra note 119 and accompanying text (discussing congressional limits placed on the ability of the Executive to initiate special activities without giving prior notice to Congress).

${ }_{13}$ See Goldwater, supra note 8, at 18 ("The U.S. intelligence system is the most public intelligence system in the world"); see also J. Ranelagh, The Agency: The RISE AND DECLINE of THE CIA 16-17 (1987) ("[The CIA] is the most public of the world's secret intelligence services, having its own press office-something no European intelligence agency would dream of having."). Even Great Britain, the country whose intelligence service served as the model for our own, takes a much more secretive approach to sensitive intelligence information. The Official Secrets Act of 1911 severely restricts the distribution of classified information. See Official Secrets Act, 1911, 1 \& 2 Geo. 5, ch. 28, §§ 1-13; Palmer, The History of the D-Notice Committee, in THE Mrssing Dimension: Governments and INTElligence Communities in the Twentieth Century 227, 227-49 (C. Andrew \& D. Dilks eds. 1984) [hereinafter Missing Dimension]. There is some evidence that Britain may move toward a more public "American" approach. See Supperstone, The Law Relating To Security in Great Britain, in APPROACHES TO INTELLIGENCE, supra note 2, at 218-43 (describing the impact of recent American judicial and legislative approaches on British perspectives); Raines, Britain's Secrets Face New Battle, N.Y. Times, Oct. 29, 1987, at A11, col. 1. 
ing secrets to adversaries. ${ }^{14}$ When evaluating intelligence oversight legislation or proposals, the paramount question is: What kind of oversight is possible, and how shall it be implemented and enforced?

Malfunction in, and dissatisfaction with, the oversight mechanism is inevitable when broad policy disputes between the executive and legislative branches are waged within the narrow confines of intelligence oversight. $^{15}$ Reform proposals cannot succeed without providing for a means of resolution outside those narrow confines. ${ }^{16}$ Since the more formal intelligence oversight process began in the mid-1970s, however, such a resolution has become increasingly difficult. Seeking to maximize their institutional interests, both branches have increasingly resorted to legalistic approaches to intelligence oversight. ${ }^{17}$

But as of today, America is unique in its willing exposure of its intelligence service to the public.

14 History has demonstrated the risks inherent to the mechanism for congressional oversight of intelligence activities. For example, in 1975, the Pike Committee ignored objections by the Executive and unilaterally decided to declassify transcripts that revealed the National Security Agency's capability of monitoring Egyptian communications during the 1973 Arab-Israeli war. See L. Johnson, supra note 8, at 78-79; see also C. Crabb \& P. Holt, Invitation to Struggle: Congress, the President AND Foreign Policy 150-52 (1980) (describing Pike Committee and the role of Rep. Harrington, who admitted leaking confidential information relating to CIA activities in Chile but was unrepentant).

Other incidents of congressional leaks of intelligence information include the inadvertent listing of a secret organization in a Senate Report. The result was a full scale expose of the secret organization. See S. REP. No. 466, 93d Cong., 1st Sess. (1973); Caldwell, Button the Loose Lips in Congress, San Diego Union, July 26, 1987, at 1. In a more recent incident, Rep. Zablocki reportedly leaked the details of a plan to topple Libyan leader Muammar Quaddafi. See B. WoodWARD, supra note 6, at 15860; see also infra note 163 and accompanying text.

On the whole, Congress' record is neither as good as it might wish nor as bad as its detractors often suggest, but the risk is real.

16 See A.B.A. Evaluation, supra note 11, at 21-23 (describing controversy surrounding covert action funding as struggle between the executive and legislative branches); see also Karalekas, Intelligence Oversight: Has Anything Changed?, 6 WASH. Q., Summer 1983, at 22, 30 (noting that changing and undefined congressional policy priorities have placed the intelligence committees into a position of uncertainty as the focus point for inter-branch conflict).

${ }^{16}$ Cf. Karalekas, supra note 15 , at 30 ("[T] emerged from the period of congressional investigations were disproportionately fixed on statutory and procedural remedies for issues that remain difficult both to define and to reach agreement on in those terms.").

17 See supra note 5 \& infra notes 44-47, 83-84 and accompanying text (describing the Hughes-Ryan, Clark, and Boland Amendments). This trend toward legalization is not restricted to legislation. For example, Michael Malbin has noted that the congressional investigation of the Iran-Contra episode was conducted in an almost entirely "legalesque" mode, with criminal lawyers and the majority "making obedience to the law [their] central theme." See M. Malbin, Legalism Versus Political Checks and Balances: Legislative-Executive Relations in the Wake of Iran-Contra 15 (April 9, 1988) (draft of paper presented at the American Enterprise Institute conference on "The Embattled Executive"); see also Koh, Why the Executive (Almost) Always Wins in Foreign Affairs: Lessons of the Iran-Contra Affair, 97 YALE L.J. 1255, 1275 (1988) ("By 
Recourse to these formalistic "legal" oversight approaches will not serve to create a stable basis for guidance of intelligence activities. For legalesque approaches-either in budgetary or in statutory terms-inherently are preoccupied "with preventing the occurrence... of objectionable actions and ignoring the problems of inducing desired behavior patterns."18 Furthermore, the policy implications for "legalesque" oversight techniques are vast, for by their unavoidable retroactive nature, they potentially threaten the operational stability of U.S. intelligence entities. The United States urgently needs a stable intelligence regime, for as the world becomes increasingly less malleable to the overt use of U.S. force or influence, the need for an effective and accountable intelligence capability will increase. ${ }^{19}$

adopting a quasi-judicial tone for their report, the Iran-Contra Committees compounded their failure to recognize historical patterns . . . Congress played both judge and prosecutor."). Furthermore, the Executive also resorted to legal means to support policy preferences. While Congress has significant restrictions on the sale of weapons abroad, such as the International Arms Export Control Act of 1976, Pub. L. No. 94329, 90 Stat. 729 (codified as amended at 22 U.S.C. $\$ 2318$ (1982 \& Supp. IV 1985)), the Executive argued that ambiguities about how this law interacted with covert action supported the Executive's position in the Iran-Contra scandal. See, e.g., IRAN-ConTra REPORT, supra note 3, at 541. In addition, the Executive sought a legal opinion from a very young lawyer very low in the Executive's legal hierarchy to support its contention that the National Security Council was not within the scope of the Boland Amendments' restrictions on aid to the rebel forces in Nicaragua-despite the obvious political ramifications of using such a technical loophole. See id. at 400 .

The use of the law has been an attempt by all parties not to shape policy but to determine outcomes-in intelligence activities, however, the law can only be used thus retroactively. For a critique of this approach, see Hastedt, Controlling Intelligence: The Role of the DCI, INT'L J. INTELLIGENCE \& COUNTERINTELligenCE, Winter 1986 , at $25,25-27$.

${ }_{18}$ Hastedt, supra note 17, at 26; see also Koh, supra note 17, at 1274 (noting that "[i]n a familiar regulatory pattern, Congress' successive efforts to catch-up with Executive evasion of its legislative controls served only to shift Executive activity"); Toensing, Congressional Oversight: Impeding the Executive Branch and Abusing the Individual, 11 Hous. J. INT'L L. 169, 173 (1988) (noting that Congress passes oversight laws or restrictions such as the Boland Amendment "where the language is not crafted with the specific culpable intent required in criminal laws, and where the language also contains the murkiness and obfuscation permitting a broader political spectrum to vote for them").

${ }_{19}$ This statement is, of course, a value-laden prediction. Overextension and weakening of U.S. power, however, and its debilitating effects on national security has been widely noted for some time. A representative work of this genre is P. KENNEDY, THE Rise and Fall of the Great Powers: Economic Change and Military ConFLICT FROM 1500 ro 2000 (1987) (noting the historical cycle of expansion, economic weakening, and eventual contraction of powerful nations). See also Schlesinger, "We Sometimes Forget . . . How Powerful this Nation Is," N.Y. Times, June 19, 1988, § 6 (Magazine), at 35, 35 (noting widespread predictions of U.S. overextension and decline among decisionmaking elites).

The need for good, accurate, and effective intelligence will become even more critical as our resources become more constrained. Yet, the U.S. is not configured for this eventuality. Conventional military power will not arguably address the greatest threat to future U.S. security: the spectrum of conflict known as "low intensity conflict," and 
The entire debate between the executive and legislative branches on intelligence questions centers on the constitutional allocation of power between the branches. This Comment argues that there is no clear constitutional delineation of responsibility for intelligence activities, but that application of the proper separation of powers analysis requires a balancing of branch interests ${ }^{20}$ that leaves the executive more latitude than is contained in many of the post-Iran-Contra legislative proposals. ${ }^{21}$ The balancing test presented below is based on a functional approach to intelligence activities, disaggregating broad terms such as "special activity" into discrete categories based on the nature of the activity in question. While Congress's oversight interests and rights are strongest in the area of paramilitary activity, provisions requiring that Congress be given prior notice of such activities or instituting a statutorily defined definition of "timeliness" of such notice are too broad and thus unconstitutional. This analysis reveals a more limited legal basis for congressional oversight than some in Congress articulate. $^{22}$

"amorphous wars." See T. Franck, Improving the Performance of Congress in Foreign Policy 2 (March 30, 1988) (paper presented to the ABA Standing Committee on Law and National Security) (on file at the University of Pennsylvania Law Review) (noting that our enemies "train, arm and finance terrorist groups and insurgencies which nibble at the periphery of our sphere of interest and bore at our national security in ambiguous, but efficient fashion"). This type of conflict poses indirect threats and demands a subtle application of countervailing power. And " $t]$ he intelligence-policy connection is especially strained in situations characterized by ambiguous threats to U.S. security, [and] by substantial disagreement among [U.S.] policy elites about how to respond." Cimbala, Amorphous Wars, 2 INr'L J. INTELligence \& CounTERINTELLIGENCE 73, 73 (1988). Yet these "amorphous wars" will continue to grow in number, importance, and scope, requiring effective and flexible intelligence capabilities. See generally J. AdAMS, SECRET ARMies: Inside the AMERICAN, Soviet and EuRopean SPECIAL ForCES 390-98 (1987) (noting the disorganization of Western approaches to low intensity conflict).

20 Thus, along the traditional spectrum of functional versus formalist constitutional analysis, this Comment employs a functional approach. For an explanation of why such a test is appropriate for the subject see infra notes 110-26 and accompanying text. While this Comment stresses the complex interaction between the branches and employs a test based on juridical standards to delineate the boundaries of permissable oversight, it does not seek to refute Dean Jesse Choper's notion that the system ultimately is self-correcting and best left alone from judicial interference. See J. CHOPER, Judicial Review and the National Political Process 273-275 (1980). The functional balancing test provides the contours within which a purely political interbranch compromise can be negotiated and ratified through practice. See infra notes 158-82 and accompanying text.

${ }_{21}$ See, e.g., S. 1721, 100th Cong., 2d Sess. (1988) ("Intelligence Oversight Act of 1988"); H.R. 1371, 100th Cong., 1st Sess. (1987) ("Covert Action Notification Act of 1987); H.R. 1013, 100th Cong., 1st Sess. (1987) ("Intelligence Oversight Amendments of 1987 ').

${ }^{22}$ This Comment implicitly rejects the notion that Congress has a right to oversee all intelligence activities and hence a right to all intelligence information. Many scholars and congressional partisans, however, believe that Congress does have a right to 
Given the legal parameters established above, this Comment advocates abandoning recourse to statutory law to enforce policy preferences in favor of a mechanism that is instead based on the recognition that stable and effective oversight must entail compromise, flexibility, and genuine political dialogue between the Executive and Congress in order to serve the needs of both branches and the Nation.

Part One defines the term "intelligence" as it is used in this Comment, and will briefly describe the composition of the intelligence community. Part Two explores the relationship between constitutional provisions for intelligence activities and congressional and executive power over the conduct of foreign affairs. This Part also assesses the constitutionality of congressional attempts to restrict or interfere with executive discretion in intelligence activities, particularly as they relate to the congressional requirement of prior or "timely" notice of covert activities. Part Three focuses on the need to create a more stable relationship between Congress and the Executive than that provided by the legal formalism produced by arguing constitutional extremes.

The Comment concludes by proposing a departure from the current trend of legally rigid and ossified statutory oversight mechanisms to one featuring political compromise and flexibility, supplemented by modest structural changes in both legislative and executive oversight institutions, and by statutory changes in the Intelligence Oversight Act of 1980. The goal of this proposal is to maximize efficiency and accountability.

limitless oversight of intelligence activities. See H.R. 1013, H.R. 1371, and Other Proposals Which Address the Issue of Affording Prior Notice of Covert Actions to the Congress: Hearings Before the Subcomm. on Legislation of the House Permanent Select Comm. on Intelligence, 100th Cong., 1st Sess. 137 (1987) [hereinafter Covert Hearings] (statement of William G. Miller, former Staff Director of the Senate Select Committee on Intelligence) (noting that "all intelligence information should be available to the Congress without exception"); C. CRABB \& P. HolT, supra note 14, at 137 ("In its fundamentals, the relationship of Congress to the intelligence community is, or should be, no different from its relationship to other parts of the executive branch."); see also L. Fisher, Understanding the Role of Congress in Foreign Policy 13 (March 30,1988 ) (paper presented to ABA Standing Committee on Law and National Security) (on file with the University of Pennsylvania Law Review) ("Congress has extensive powers in foreign affairs, including not only the powers specifically enumerated in the Constitution but also those implied in the effective functioning of government."). By this, presumably, Fisher sees no effective limit on the scope of congressional intelligence oversight authority. 


\section{The Intelligence Community and Congressional OVERSIGHT}

\section{A. Intelligence and the Intelligence Community}

Intelligence is "information or knowledge; as operational activity designed to acquire, exploit, or protect knowledge; and as organization developed for those purposes."23 Intelligence is more than information; it is the product of processed information. ${ }^{24}$ Accordingly, this Comment focuses on the generation of a specific product (or activity) and the interaction of that process with decisionmaking elites.

As traditionally understood, there are three types, or genres, of intelligence activities: collection, counterintelligence, and special activities. Special activities are frequently referred to as covert action. ${ }^{25}$ Intelligence "collection" is the acquisition of any information that might be required by end-use consumers, such as analysts, policymakers, or agents. Intelligence is collected through the use of human sources ("HUMINT"), photo/image technologies ("PHOTOINT") and signals sources ("SIGINT"). ${ }^{26}$

Counterintelligence is the process of neutralizing foreign hostile intelligence services through acquiring information or pursuing other activities. This discipline has subgenres, such as the debriefing of defectors, entrapment of foreign personnel, direct penetration of hostile services, or disruption of individual operations. ${ }^{27}$

Special activities are operations designed to influence foreign governments, people, or events surreptitiously, in ways that benefit the

${ }^{23}$ Godson, supra note 2, at 4 (quoting the eminence grise of American strategic analysts, Sherman Kent (emphasis omitted)). A more common perception is of intelligence as merely information. See, e.g., J. OsETH, supra note 7, at 12 (Intelligence is "evaluated information compiled to apprise and instruct national decisionmakers about situations requiring or likely to require their attention.").

${ }^{24}$ For the classic study of how cognitive dissonance-that is, failure to process information properly-led to an intelligence failure, see $\mathrm{R}$. WOHLSTETTER, PEARL HARBOR: WARNING AND DECISION 382-401 (1962) (knowledge of Japanese intent to attack Pearl Harbor was available, but analysis and distribution systems failed to transform this information into intelligence available to American decisionmakers).

26 Some purists object to including covert action in the definition of intelligence, but it is clear that the CIA considers covert action to be an intelligence function. See Central Intelligence Agency, U.S. Intelligence During the War for IndePENDENCE 16-19 (1976). Many informed observers also share this view. See, e.g., Godson, supra note 2, at 25-27 (placing a discussion of covert action within the context of an overview of the American intelligence process).

${ }^{26}$ See, e.g., J. Bamford, The Puzzle Palace $377-78$ (1982) (describing the differences between the three techniques).

${ }^{27}$ See Zuehlke, What is Counterintelligence?, in INTELLIGENCE REQUIREMENTS FOR THE 1980's: CounterintelligenCE 13, 29-30 (R. Godson ed. 1980) (describing basic forms and features of aggressive counterintelligence). 
sponsor. ${ }^{28}$ While commonly confused in the public mind with purely paramilitary activity, special activities include paramilitary operations, but also political actions directed toward destabilization, exfiltration and infiltration activities, support for causes and individuals such as newspapers, insurgents, labor unions or political parties, and disinformation. ${ }^{28}$

The Central Intelligence Agency is only one of a handful of intelligence organizations, some of which dwarf the CIA in terms of manpower, budgetary resources, and capabilities. ${ }^{30}$ The most obvious players in the intelligence community include the CIA, the State Department's Bureau of Intelligence and Research ("INR"), ${ }^{31}$ the Na-

${ }^{28}$ Special activities is a catchall phrase embodying a wide variety of activities. CIA legend Richard Bissel stated covert action included: political advice and counsel; subsidies to an individual; financial support and "technical assistance" to political parties; support of private organizations including labor unions, business firms, cooperatives, and the like; covert propaganda; "private" training of individuals in and exchanges with friendly intelligence services; economic operations; and paramilitary or political action operations designed to overthrow or support a regime. See J. OsETH, supra note 7, at 27-28; see also Reagan Exec. Order No. 12,333, supra note 7, at 215 (defining special activities as "activities conducted in support of national foreign policy objectives abroad which are planned and executed so that the role of the United States Government is not apparent or acknowledged publicly. . . .").

The U.S. Senate recently sought to define special activities using text from the Hughes-Ryan Amendment and President Reagan's executive order. See S. REP. No. 276, 100th Cong., 2d Sess. 38 (1988) (noting that the term "special activity" for purposes of the Intelligence Oversight Act of 1988 was intended to incorporate the "mutually agreed upon" definitions of both documents).

${ }_{28}$ See J. Richelson, The U.S. Intelligence Community 3 (1985) (defining various tasks for covert action). Paramilitary activities involve the "active direction, deployment, or support of regular or irregular armed bodies of men employing unconventional military means to achieve their (or their sponsor's) political objectives." See Charters, The Role of Intelligence Services in the Direction of Covert Paramilitary Operations, in POLICY AND PROCEss, supra note 1, at 334. Although the CIA is currently comprised of both analytical and operational functions, it was not originally created as such. Some argue that the CIA's covert paramilitary function should be separated from the rest of the agency. See id. at 339 (noting the success of the British use of the SAS in the 1970's to quell the Dhofar Rebellion in Oman); Lockhart, supra note 2, at 37-38 (arguing that paramilitary operations are most effectively conducted by the military, citing the Bay of Pigs fiasco and the French SDECE failure in Algeria as examples).

${ }_{30}$ While the public generally credits the CIA as the most powerful or secretive of the intelligence agencies, it is neither. The CIA actually accounts for a mere 15 percent of the intelligence community in terms of manpower, and less in terms of budgetary control. The majority of assets and control actually resides in the hands of the Secretary of Defense, whose department controls about 80 percent of the money allocated to intelligence. See J. RANELAGH, supra note 13, at 548-549; J. Richelson, supra note 29, at 279. According to former DCI Richard Helms, "when the 'DCI clashes with the secretary of defense, he isn't a big enough fellow on the block." "Hastedt, supra note 17 , at 35.

${ }^{31}$ INR is comprised of the remnants of the old research and analysis wing of the now-defunct Office of Strategic Services ("OSS"), which were transferred to the State Department after World War II. The remainder of OSS, mainly its clandestine activi- 
tional Security Agency ("NSA"), ${ }^{32}$ the Defense Department's Defense Intelligence Agency ("DIA"), and photo-intelligence organizations in the Pentagon that jointly supervise the nation's space-based assets with the Director of Central Intelligence. ${ }^{38}$ The armed services each have an intelligence section. On domestic issues and foreign counterintelligence, the FBI has significant resources and preeminence. ${ }^{34}$ Even other departments often not associated in the public mind with intelligence have peripheral intelligence functions. ${ }^{35}$ Of these organizations, only the GIA, NSA, and the photo-intelligence resources in the Pentagon are national intelligence organizations; they perform intelligence for the entire government, not any single department. Any oversight mechanism has to be broad and flexible enough to encompass the entirety of the intelligence community and the realities of the fragmented power within it. $^{36}$

ties and administrative staff, was transferred to the War Department. See B. SMITH, THE SHADOW WARRIORS 406 (1983).

${ }_{32}$ The National Security Agency is the largest member of the intelligence community, and one of the most secretive. The NSA was created by the Executive Branch by executive order; upon its inception, no mention of the NSA was made in the Government Organization Manual, the Federal Register, or the Congressional Record. The order creating the NSA was classified top secret with a code word that was itself classified. See Senate Select Commitee to Study Government.Operations With Respect to Intelligence Activities, Supplementary Detailed Staff RePORTS ON INTELligence ACTIVITIES AND the RightS OF AMERICANS, BOOK III, S. REP. No. 755, 94th Cong., 2d Sess. 736 (1976); J. BAMFORD, supra note 26, at 1-2. While the collective reconnaissance budget in the Pentagon is the largest item in the intelligence budget, the Director of the NSA oversees the largest single unified program as Chief of the Central Security Service. See J. Richelson, supra note 29, at 19-20.

${ }^{33}$ These assets are supervised by a national level organization within the Air Force while the Director of Central Intelligence (DCI) and the Secretary of Defense have final control of asset deployment. The name of this organization is still officially "black," or secret.

s4 See Reagan Exec. Order No. 12,333, supra note 7, at 210; see also M. LowENTHAL, U.S. INTELligence: Evolution AND ANATOMY 98 (1984) (describing the F.B.I. as the "paramount agency" in the counterintelligence field); S. UNGAR, FBI: AN UNCENSORED LOOK BEHIND THE WALLS 109-18 (1976) (describing the Bureau's organization and counterintelligence effort against the Soviet GRU and KGB); Elliff, The Attorney General's Guidelines for FBI Investigations, 69 CORNELL L. REv. 785 (1984) (noting changes in FBI guidelines during the Reagan Administration that have increased the Bureau's latitude in domestic security matters).

ss The the Office of Intelligence Support of the Department of Energy, the Department of Agriculture's Foreign Agriculture Service, the Drug Enforcement Agency, and even the Federal Research Division of the Library of Congress all have intelligence-related missions. See J. Richelson, supra note 29, at 95-104.

There is no statutory definition of the intelligence community, but President Reagan's executive order defines the intelligence community as the CIA, the NSA, the DIA, the photo-intelligence and reconnaissance offices in the Pentagon, INR, the staff elements of the Director of Central Intelligence, and the intelligence elements of the armed forces, the F.B.I., the Department of the Treasury, and the Department of Energy. See Reagan Exec. Order 12,333, supra note 7, at 215.

so This assumes, of course, that the reform does not grant the DCI the actual 


\section{B. Congressional Oversight of Intelligence Activities}

Study of intelligence oversight practice is useful to establish the contours of cooperation possible in the era following the Iran-Contra incident. The oversight odyssey has traveled through all three phases of Justice Jackson's famous quasi-algebraic formula describing the interrelationship of executive and congressional powers in Youngstown Sheet \& Tube Co. v. Sawyer. ${ }^{37}$ Congress has historically vacillated between benign neglect of its oversight power and zealous overreaching. The current reform impulse demonstrates renewed congressional desire to increase its oversight role by means of a legalistic approach. Understanding how this state of affairs came into existence may reveal a path to a more stable relationship between the Executive and Congress in the area of intelligence oversight.

Prior to the 1970 s, Congress rarely interfered with the President's use of intelligence resources and was reluctant to take an active oversight role. For example, Senator Ellender, while serving as Chairman of the Senate Appropriations Intelligence Operations Subcommittee, reportedly said that he did not want to learn details of the CIA budget for fear that he might talk in his sleep. ${ }^{38}$

power and authority in the intelligence community to control its resources and be held accountable for performance of the entire intelligence effort. As originally conceived, the CIA "was to establish an organization that would coordinate the intelligence activities of the various other U.S. intelligence components and take the results of this work . . . to produce a common estimate." J. RICHELSON, supra note 29 , at 338 . The central coordinating role was abdicated by Allen Dulles, who remained fascinated by covert action and clandestine collection. The fissures in the intelligence community today are due in part to his dislike of the DCI's community management role. See, e.g., id. at 338-342 (describing how even Eisenhower despaired of ever getting Dulles to perform community management functions). Given the entrenched political and bureaucratic interests in the current diaphonous arrangement, the current diffusion of power in the intelligence community is unlikely to change absent a sufficiently strong galvanizing situation such as a national calamity.

${ }^{37} 343$ U.S. 579 (1952). There, Justice Jackson said that when "the President acts pursuant to an express or implied authorization of Congress, his authority is at its maximum," and when the President acts withnut such an authorization, "he can only rely upon his own independent powers," but when the President acts against the express or implied will of Congress, "his power is at its lowest ebb." Id. at 635, 637 (Jackson, J., concurring).

${ }^{38}$ See Nomination of William E. Colby: Hearings on the Nomination of William E. Colby to the Director of Central Intelligence Before the Senate Comm. on Armed Services, 93d Cong., 1st Sess. 52 (1973) (remarks of Senator Hughes); 120 ConG. REC. 17,492 (1974) (same); .

Past efforts by some senators to secure greater oversight of intelligence matters were not greeted with strong support. For instance, Senator Mansfield received only 27 votes in support of his oversight bill introduced in 1955. Mansfield's proposal was to create a joint intelligence committee modeled after the Joint Committee on Atomic Energy, created in 1946. See C. CRABB \& P. Holt, supra note 14, at 141. After the Bay of Pigs fiasco, Senator Eugene McCarthy attempted and failed to secure support for 
From the 1950 s to the early 1970 s, Congress preferred an informal oversight mechanism, ${ }^{39}$ in part, because of the perceived low political payoff of intelligence oversight. ${ }^{40}$ In the midst of hearings investigating the CIA's involvement in Chile, Senator Hubert Humphrey declared: "I have to go now. I am trying to get jobs for 400 people in Minnesota today. That is a great deal more important to me right now than Chile." 11 This attitude led to an atmosphere in which accountability was the exception, and leniency the rule. ${ }^{22}$ This atmosphere under-

intelligence oversight. See J. RANELAGH, supra note 13, at 479. After the Dominican intervention in 1965, McCarthy tried and failed again, this time by a vote of 61-28. See C. CRABB \& P. HolT, supra note 14 , at 479.

39 From the time of the CIA's establishment in 1947, its funding was "concealed in appropriations for other agencies, mainly the Defense Department." C. CRABB \& P. HoLT, supra note 14, at 140; see also CIA: Congress in Dark About Activities, Spending, 29 Cong. Q. 1840, 1840 (1971) (noting the failure of some 200 bills, over a twenty year period, aimed at making the CIA "more accountable."). While four subcommittees of the House and Senate Armed Services and Appropriations Committees were theoretically in an oversight function, the subcommittees convened infrequently and "sometimes went a whole year without meeting." C. CRABB \& P. HoLT, supra note 14, at 140; see also L. JoHNson, supra note 8, at 7 (also noting the infrequency with which these subcommittees met).

According to former Secretary of State Dean Rusk, the President and two or three people in the Bureau of the Budget were the only people outside the CIA who saw the CIA budget before it was turned over to Senator Russell, Chairman of the Senate Armed Services Committee, who would then bury it in the defense budget without hearings, questions, or complaints. His judgment was the final word. See id. at 6-7; T. PowERS, supra note 6 , at 276 (detailing the immense power wielded by Senator Russell); see also C. CRABB \& P. Holt, supra note 14, at 140 (noting that the NSA's "existence was scarcely acknowledged for years").

40 See Karalekas, supra note 15, at 27 (noting that "[w]hile the period of the investigations [provides] high visibility and assured headlines, ongoing oversight is shrouded in secrecy without a public constituency").

${ }^{4}$ CIA Foreign and Domestic Activities: Hearings on Activities of the Central Intelligence Agency in Foreign Countries and in the United States Before the Senate Comm. on Foreign Relations, 94th Cong., 1st Sess. 11 (1975).

12 For example, CIA-sponsored reconnaissance planes such as the U-2 and SR-71 were never subjected to the criticism and scrutiny reserved for Strategic Air Command programs such as the B-52 or B-70 program. See J. RaNELAGH, supra note 13, at 481; see also C. CRABB \& P. HolT, supra note 14, at 137 (noting that "[t]he intelligence community had been conditioned by more than a quarter century of experience not to tell Congress what it was doing. And Congress has been conditioned not to ask").

Even CIA paramilitary activities were usually given only cursory attention, if any. When it became public that the agency was secretly supporting a 36,000-man Laotian army during the Indochina conflict, Senator Fulbright asked Senator Ellender if the CIA had come before the oversight committee for approval. Ellender responded, "Probably," adding, "[but] I did not know anything about it." 117 CoNG. REc. 42,929 (1971) (Ellender was Chairman of the Appropriations Intelligence Oversight SubCommittee); see also L. JoHnSon, supra note 8, at 5-6 (describing the story of how during a congressional briefing on CIA paramilitary activity, a bored, inattentive, and occasionally slumbering congressman thought the briefing was on parliamentary activity).

Of the entire intelligence community, the NSA has traditionally enjoyed the most protection, with Senator Russell once reportedly asking during a briefing, "What does 
went a radical change in the mid-1970s.

\section{Congressional Oversight in the 1970 s}

The mid-1970s saw significant changes in Congress's role in intelligence oversight. After revelations about the CIA's role in the 1973 destabilization of the Chilean economy of Salvador Allende, ${ }^{43}$ Congress passed the Hughes-Ryan Amendment to the 1961 Foreign Assistance Act. ${ }^{44}$ With the Hughes-Ryan Amendment, Congress passed the first statutory provision regulating foreign intelligence activities, particularly special activities. The Act prohibited expenditure of funds for covert actions unless the President made a personal "finding" that the action was necessary and reported the finding to "the appropriate committees of the Congress,"45 numbering six at the time, ${ }^{46}$ in a "timely fashion." 47 The Act did not require committee approval, but many felt the number of committees and the corresponding risk of leaks would force the Executive to minimize the number of politically sensitive covert activities. $^{48}$

After the Hughes-Ryan Amendment, Congress established a more formal committee structure to oversee U.S. intelligence activities. In 1976, the Senate established the Senate Select Committee on Intelligence. ${ }^{49}$ A year later, the House created the House Permanent Select

the NSA do?" See T. Powers, supra note 6, at 276.

${ }^{4}$ See C. CRABB \& P. Holr, supra note 14, at 145-46 (describing congressional inquiry into the CIA's role in Allende's downfall); see also J. RANELAGH, supra note 13 , at 610 (interpreting the Hughes-Ryan Amendment as a reaction to CIA attempts to prevent Allende's election).

14 Foreign Assistance Act of 1974, Pub. L. No. 93-559, § 32, 88 Stat. 1795, 1804-05 (codified as amended at 22 U.S.C. $\S 2422$ (1982)).

${ }^{45}$ See id.

46 See C. CRABb \& P. Holt, supra note 14, at 147.

17 Foreign Assistance Act of 1974, Pub. L. No. 93-559, § 32, 88 Stat. 1795, 1804 (codified as amended at 22 U.S.C. $§ 2422$ (1982)).

48 See, e.g., ABA Evaluation, supra note 11, at 10. Initially, the Hughes-Ryan Amendment did not pose a problem for the Carter administration, since the Carter regime was less inclined to consider covert action a useful tool. Only after the Iranian and Afghan debacles did the Carter administration belatedly seek to rebuild the covert action arm of the CIA devastated by DCI Stansfield Turner. See J. RANELAGH, supra note 13, at 644-648, 652 ("The effective closedown of the clandestine service was another indication of U.S. withdrawal. The whole history of America in the world is one of intervention followed by departure, and Turner was ensuring that the CIA mirrored this."); id. at $645 \mathrm{n}^{*}$; see also Karalekas, supra note 15, at 28 (discussing the heightened interest by the Carter Administration in covert action in response to the hostage taking in Iran and the Soviet invasion of Afghanistan).

49 See S. Res. 400, 94th Cong., 2d Sess., 122 Cong. Rec. 14,673, 14,673-75 (1976). The significance of budgetary oversight was underscored in section 12 of the resolution, which provided that after September 30,1976-the start of the fiscal year 1977 budget-no funds would be appropriated for the CIA, NSA, DIA, the FBI's 
Committee on Intelligence, with similar authority. ${ }^{50}$ Both the House and Senate resolutions limited membership to a fixed time period to prevent either committee from becoming too close to the community it was intended to oversee. ${ }^{51}$ The addition of these two oversight committees raised the number of committees to which the Executive had to report under the Hughes-Ryan Amendment to eight. ${ }^{62}$

Congress strengthened its oversight power once again through the Intelligence and Intelligence-Related Activities Authorization Act for Fiscal Year 1979. ${ }^{53}$ That Act placed intelligence agencies on the same annual authorization and appropriation basis as other executive branch agencies. ${ }^{54}$ In doing so, Congress used its power of the purse to reinforce its oversight powers, not just for covert activities, but for the entire range of intelligence activities.

Congress's efforts to strengthen its oversight of intelligence activities went beyond the creation of new committees and budgetary procedures. Congress included a charge to draft a charter for the intelligence community in the hope of providing a comprehensive basis for both executive and congressional oversight of intelligence activities. ${ }^{55}$ The task of drafting such a charter proved to be problematic, ${ }^{56}$ and the pro-

Intelligence Division, and other Defense Department intelligence activities unless such funds were authorized by a bill or joint resolution passed by the Senate. See id. $\S 12$, 122 CONG. REC. at 14,675 .

so See H.R. Res. 658, 95th Cong., 1st Sess., 123 Cong. Rec. 22,932-34 (1977). As was the case with S. Res. 400, H.R. Res. 658 provided for budgetary control. Compare S. Res. 400, § 3(a)(4), 94th Cong., 2d Sess., 122 Cong. REc. 14,673, 14,673 (1976) (requiring that authorizations for appropriations be submitted to the Senate Intelligence Committee) with H.R. Res. 658, \& 2(a)(4), 95th Cong., 1st Sess., 123 CoNG. REc. 22,932, 22,932-33 (1977) (requiring that authorizations for appropriations be submitted to the House Intelligence Committee).

H.R. Res. 658, unlike S. Res. 400, permitted the House committee to oversee tactical military intelligence in addition to the activities of the intelligence agencies. This permitted the House Committee the authority to oversee intelligence related activities ("IRA") funding in DoD. See 123 CoNG. REC. 22,941-42 (1977) (summary of significant differences between S. Res. 400 and H.R. Res. 658). Compare H.R. Res. 658, § 2(10)(a), 95th Cong., 1st Sess., 123 Cong. REc. 22,934 (1977) ("[I]ntelligence and intelligence related activities" does not exclude tactical foreign military intelligence.) with S. Res. 400, § 14(a), 94th Cong., 2d Sess., 122 Cong. REc. 14,675 (1976) ("I]ntelligence and intelligence related activities" excludes "tactical foreign military intelligence serving no national policymaking function.").

51 See ABA Evaluation, supra note 11, at 8.

s2 See C. CRABB \& P. Holt, supra note 14, at 146-47.

${ }^{63}$ Pub. L. No. 95-370, 92 Stat. 626 (1978).

o4 See ABA Evaluation, supra note 11 , at 8.

o5 See H.R. Res. 658, \& 3(a)(2), 95th Cong., 1st Sess., 123 Cong. Rec. 22,932, 22,934 (1977); S. Res. 400, § 13(a)(2), 94th Cong., 2d Sess., 122 Cong. Rec. 14,673, 14,675 (1976).

${ }_{B B}$ In the words of a former congressional staffer on the Church Committee, "The qualitative aspects of intelligence analysis, the intricacies of clandestine collection, and problems of cover, among others, simply did not find ready solution in the fixed lan- 
posal that eventually emerged ${ }^{57}$ met with heavy opposition from the Carter administration. ${ }^{58}$ Congress's charter proposal ultimately yielded a compromise; negotiations between the Executive and the intelligence committees produced the Intelligence Oversight Act of $1980 .^{59}$

\section{The 1980 Oversight Act}

The Intelligence Oversight Act of 1980 requires the Executive to keep Congress "fully and currently informed" of all intelligence activities, but reduces the number of intelligence oversight committees from eight to two ${ }^{60}$ While the Act generally requires prior notice of special activities, ${ }^{61}$ it permits the President-under special circumstances-to act first and notify Congress after the fact. ${ }^{62}$

The 1980 Act was considered to be an acceptable framework for intelligence oversight, and through the 1980s, it proved fairly effective. A controversial exception to the provision of prior notice was the CIA's 1984 mining operation in Nicaraguan waters. ${ }^{63}$ The resulting uproar led to a negotiated settlement in 1984 (with an addendum in 1986) between Director of Central Intelligence (DCI) William Gasey and the Senate Intelligence Committee. ${ }^{64}$

This agreement formalized "the requirement that the Director report any significant anticipated intelligence activity, including instances in which the activity would be part of an ongoing program." ${ }^{\prime 65}$ The only major deviation from the pattern of executive compliance since this agreement was the Iran-Contra incident, which has generated the larg-

guage of the law." Karalekas, supra note 15, at 25.

${ }_{57}$ See S. 2525, 95th Cong., 2d Sess. (1978) ("National Intelligence Reorganization and Reform Act of 1978').

${ }^{58}$ See J. OsETH, supra note 7, at 139.

so 50 U.S.C. § 413 (1982); see ABA Evaluation, supra note 11, at 11-12; J. OSETH, supra note 7, at 142 .

${ }^{60} 50$ U.S.C. $\S$ 413(a)(1) (1982); see ABA Evaluation, supra note 11, at 12.

${ }^{61}$ See 50 U.S.C. \& 413(a)(1) (1982).

62 See id. § 413(b).

${ }^{63}$ Both the Senate and the House committees were informed of the mining operation but, unlike the House committee, the Senate committee had not pulled the facts of several briefings together. See Covert Hearings, supra note 22, at 246. But see S. REP. No. 276, supra note 28, at 16-17 (Senate committee's account of the incident).

of This settlement was known as the "Casey Accords." For a copy of the signed documents, see Covert Hearings, supra note 22, at 35-43.

${ }^{65}$ Iran-Contra RePORT, supra note 3 , at 378 . The House Committee did not demand a similar commitment from Casey, because unlike their Senate counterparts, they knew about the operation. This incident reflects the chaotic nature of the Senate staffing situation. See Covert Hearings, supra note 22, at 246; ABA Evaluation, supra note 11, at 9 . Thus, while exhibiting extremely insensitive political judgment, the CIA did not actively mislead the Senate; the committee simply did not pick up oblique references to the program in testimony. 
est furor over intelligence oversight since the Church Committee's heyday.

As a result of the Iran-Contra hearings, legislation was introduced seeking to cure a number of putative "problems" with intelligence oversight. ${ }^{66}$ Examples of some "solutions" were the creation of a new office, the National Intelligence Director, ${ }^{67}$ and a congressionally confirmed Inspector General of the GIA. ${ }^{68}$ The two proposals that generated the most support eliminated the soft definition of "timely notice" in the 1980 Act, substituting a rigid requirement of 48 hours notice. ${ }^{68}$

In sum, Congress has moved from the extreme of voluntary deference to the opposite extreme of intrusion into the Executive's discretion to conduct intelligence operations. The 1980 Act demonstrated that compromise is a viable possibility in oversight. The Iran-Contra incident, however, has prompted a swing back to the approach of the mid1970 s and a more aggressive, legalesque, and intrusive form of congressional oversight. These latest proposals are not only of questionable constitutional validity; if they are adopted, they will result in an impractical and unnecessarily confrontational approach to intelligence oversight.

\section{Intelligence Oversight and Competing Claims to Constitutional Power}

The nature of intelligence oversight disputes between Congress and the Executive is that of competing claims to constitutional power. The Constitution does not overtly confer authority for intelligence activities to either the Congress or the President; intelligence is a derivative function of each branch's respective powers over foreign affairs. ${ }^{\mathbf{7 0}}$

68 See supra note 12 (listing oversight reform legislation).

67 See S. 1820, 100th Cong., 1st Sess. (1987) ("National Intelligence Reorganization Act of 1987"); S. 1818, 100th Cong., 1st Sess. (1987) ("National Security Reform Act of 1987") (both written by Sen. Specter).

${ }^{68}$ See S. 1458, 100th Cong., 1st Sess. (1987) ("General Accounting Office-Central Intelligence Agency Audit Act of 1987") (written by Sen. Glenn).

${ }^{68}$ See S. 1721, 100th Cong., 2nd Sess. $§ 503(a)(1)(1987) ;$ H.R. 3822, 100th Cong., 1st Sess. § 503(a)(1) (1987).

70 See L. Henkin, Foreign Affairs and the Constitution 16, 44 (1972) (power to conduct foreign affairs is undefined by the Constitution); see also Covert Hearings, supra note 22, at 219 (letter by Louis Henkin) (intelligence activities are linked to the derivative foreign affairs powers of each branch); id. at 247-73 (statement of Assistant Attorney General Charles Cooper) (intelligence is directly related to the Executive's constitutional authority to conduct foreign policy); Vance, Striking the Balance: Congress and the President Under the War Powers Resolution, 133 U. PA. L. REv. 79, 83 (1984) ("[M]any important foreign affairs powers and war powers are not expressly allocated, and even the extent of those that are allocated is unclear."). 
On the one hand, Congress's broad power ${ }^{71}$ to legislate, appropriate funds, regulate commerce, and declare war, support its claim of extensive authority to oversee intelligence activities. Conversely, the claims of presidential plenary power to conduct foreign affairs supports the claim for unfettered discretion in the area of special intelligence activities. The balance between these claims is often difficult to reach, for the grants of power to each branch in the Constitution are, to say the least, fairly nonspecific.

\section{A. Textual Analysis of the Constitution}

\section{The Constitution and Congress}

The Constitution grants several powers to Congress that create "an invitation to struggle for the privilege of directing American foreign policy"72 between the Executive and Legislative branches. Article I of the Constitution is fairly unspecific, but section 1 of that article provides that "[a]II legislative powers herein granted shall be vested in a Congress of the United States ....."7s

The Constitution also allows Congress "[to] provide for the common Defence and general Welfare of the United States"; "T4 "To declare War"; "To make Rules for the Government and Regulation of the land and naval Forces"; "To provide for calling forth the militia," and to have control over the public purse. ${ }^{77}$ Congressional partisans argue that these clauses, together with other powers such as control of commerce between nations, ${ }^{78}$ contain significant congressional power in the area of foreign affairs ${ }^{7 \theta}$ and constitute an important basis for over-

71 This Comment's analysis of congressional power does not include the letters of marque clause. See U.S. ConST. art. $1, \S 8, \mathrm{cl}$. 11 . It is a dead power, for no letter has been issued by Congress for over 120 years. Furthermore, privateering was ended by international agreement in the Declaration of Paris in 1856. For a different analysis of the clause's contemporary relevance, see Lobel, Covert War and Congressional Authority: Hidden War and Forgotten Power, 134 U. PA. L. REv. 1034 (1986).

72 E. Corwin, The Presidency: Office and Powers 201 (5 Rev. ed. 1984).

${ }^{73}$ U.S. CONST. art. I, \& 1.

74 Id. art. I, \& 8, cl. 1.

76 Id. cl. 11.

${ }^{76}$ Id. cl. 14.

77 Id. cl. 1.

${ }^{78}$ Id. cl. 15. For example, commerce has long been defined as being beyond mere trade, but is actually "intercourse." See Gibbons v. Ogden, 22 U.S. (9 Wheat.) 1, 189 (1824). The limits of the commerce power are unknown, but are as vast as any of Congress's domestic powers. The commerce power may well be an adequate basis for an impressive array of legislation relating to foreign relations. See id. at 193 (every "species of commercial intercourse between the United States and foreign nations" is within the ambit of Congress).

${ }^{70}$ For general discussion of Congress's power over foreign affairs, see H. CAR- 
sight of both collection and special intelligence activities. ${ }^{80}$

Despite its seemingly vast power, Congress has historically relied on the power of the purse to enforce oversight preferences. ${ }^{81}$ Article I, section 9, clause 7 states that "No money shall be drawn from the Treasury, but in Consequence of Appropriations made by Law; and a regular Statement and Account of the Receipts and Expenditures of all public Money shall be published from time to time." ${ }^{\prime 82}$ Some past examples of Congress using appropriations to effect its oversight and foreign policy agenda are restrictions placed on CIA assistance to anticommunist forces in Angola ${ }^{\mathbf{3 3}}$, and more recently, to anti-communist forces in Central America. ${ }^{84}$

The Constitution does not expressly grant Congress the power to investigate in the process of its legislative function. Nonetheless, the Court has continually ruled that congressional investigative power is implicit in the power to legislate. ${ }^{85}$ Quite properly, the Court has not

roll, The House of Representatives and Foreign Affairs (1958); R. Dahl, Congress and Foreign Policy (1950); L. Henkin, supra note 70.

${ }^{80}$ For a general discussion of Congress's oversight powers, see M. OGUL, Congress Oversees the Bureaucracy: Studies in Legislative Supervision (1976). See also Aberach, Changes in Congressional Oversight, 22 AM. BEHAv. SCI. 493-515 (May/June 1979); Turner \& Thibault, Intelligence: The Right Rules, ForEIGN PoL'Y, Fall 1982, at 122, 136-38 (suggesting that U.S. intelligence needs a consistent and stable system of controls).

81 According to Karalekas and most informed observers, the control of the purse is actually the only real leverage-legally or politically-that Congress has with respect to intelligence oversight. See Karalekas, supra note 15, at 28-29 (noting that the power of the purse is an extremely blunt, imprecise, and politically expensive weapon).

${ }^{82}$ U.S. CoNST. art. I, $\S 9$, cl. 7.

s3 See International Security Assistance and Arms Export Control Act of 1976, Pub. L. No. 94-329, $\S 404,90$ Stat. 729, 757-58 (prohibiting assistance of any kind to organizations conducting military or paramilitary operations in Angola unless expressly authorized by Congress), repealed by Pub. L. No. 96-533, \& 118(a)-(d), 94 Stat. 3141 (1980), repealed by Pub. L. No. 99-83, § 811, 99 Stat. 264 (1985).

84 See Further Continuing Appropriations Act for 1983, Pub. L. No. 97-377, $\S$ 793, 96 Stat. 1830, 1865 (1982); IRAN-CONTRA REPORT, supra note 3, at 395-407.

Congress does not have to appropriate funds for all intelligence operations such as special activities, or it may restrict funds for particular operations. Congress may not, however, use its control over appropriations to prevent the executive from fulfilling its constitutionally mandated functions. $C$ f. Swaim v. United States, 28 Gt. Gl. 173, 221 (1893) ("Congress may increase the Army, or reduce the Army, or abolish it altogether; but so long as we have a military force Congress can not take away from the President the supreme command. . . . Congress can not in the disguise of 'rules for the government' of the Army impair the authority of the President as commander in chief.").

8s See Eastland v. United States Servicemen's Fund, 421 U.S. 491, 506 (1975) (holding that a subcommittee's investigation concerned a subject on which legislation could be enacted); Sinclair v. United States, 279 U.S. 263, 291 (1929) (holding that power of inquiry is essential to the legislative function); McGrain v. Daugherty, 273 U.S. 135, 174-175 (1927) (noting that "[a] legislative body cannot legislate wisely or effectively in the absence of information respecting the conditions which the legislation is intended to affect or change; and where the legislative body does not itself possess 
limited Congress to the drafting and passing of legislation, but rather, broadly construes the legislative mission to include the power to investigate and oversee matters of potential legislative concern. In Watkins $v$. United States, the Court held that broad power to conduct investigations is "inherent in the legislative process." consistently reaffirmed its view that Gongress has broad power to investigate, stating that " $[t]$ he scope of [Congress's] power of inquiry, in short, is as penetrating and far reaching as the potential power to enact and appropriate under the Constitution." gate areas of potential legislative concern is not, however, unlimited. For example, Congress cannot investigate "matters which are within the exclusive province of one of the other branches of the Government."

Congress's broad legislative power, combined with its power to declare war, provide for the national defense, control commerce between nations, and control the public purse, give it ample justification to conduct extensive oversight of the Executive's intelligence activities. For example, it has been argued that since special activities frequently entail the potential involvement of U.S. troops in armed hostilities with foreign countries, Congress's power to declare war entitles it to be fully informed of all such activities. ${ }^{89}$ Similarly, the fact that a special activity may entail the use of military equipment or the involvement of military personnel, also supports Congress's right to be informed of such activities. ${ }^{90}$ Finally, Congress's broad legislative power justifies "monitoring the activities of the Executive both in terms of its compliance with existing law, and to identify areas where new laws may be needed. Special activities on occasion raise such concerns."

In sum, Congress's right to oversee the Executive's conduct of intelligence activities is rooted in the congressional powers enumerated in the Constitution, and in Congress's broad investigatory power as recognized by the Court.

\section{The Constitution and the Presidency}

Article II, granting powers to the President, is far more general

requisite information").

86354 U.S. 178, 187 (1957).

${ }^{87}$ Barenblatt v. United States, 360 U.S. 109, 111 (1959).

${ }^{88} \mathrm{Id}$. at 111-12; see also Bowsher v. Synar, 478 U.S. 714, 722 (1986) ("The Constitution does not contemplate an active role for Congress in the supervision of officers charged with the execution of the laws it enacts.")

${ }^{80}$ See S. REP. No. 276, supra note 28, at 21.

so See id.

91 Id. 
than Article I. The President is vested with the executive power over the national government. ${ }^{92} \mathrm{He}$ is the Commander-in-Chief of the army and navy; ${ }^{93}$ he has the power to make treaties with the advice and consent of the Senate; ${ }^{94}$ he may nominate ambassadors and other public ministers and consuls; ${ }^{98}$ he may receive ambassadors and other public ministers; and he has the power to faithfully execute the laws. ${ }^{96}$ These scant few words support the massive global involvement of what was once considered the most powerful office in the world.

The argument of inherent and plenary Presidential powers in foreign affairs ${ }^{97}$ is derived from the grant of executive power and Commander-in-Chief clauses. ${ }^{98}$ Consistent with the "stewardship theory" of

92 See U.S. ConsT. art. II, $\S 1$, cl. 1.

${ }^{83}$ See id. § 2 , cl. 1.

Qt See id. cl. 2.

85 See id.

${ }^{96}$ See id. \& 3.

97 The argument about what constitutes "inherent powers" versus "express powers" dates back to Washington's Proclamation of Neutrality of 1793. Hamilton, writing under the pseudonym of "Pacificus," defended the action by stating that the powers and functions in article II were merely indicative of the powers available to the President and were not a limiting catalogue of express grants. Madison, responding under the pseudonym "Helvidius," challenged this interpretation as an attempt to build royalist prerogatives into the Presidency. See E. Corwin, The President's Control of ForEIGN RELATIONS 7-21 (1917).

The courts have upheld some aspects of Hamilton's notion of inherent powers; they have supported the principle of the removal power, see Morrison v. Olson, $108 \mathrm{~S}$. Ct. 2597, 2619-22 (1988), and the President's power to interpret treaties. See Goldwater v. Carter, 617 F.2d 697, 706-09 (D.C. Cir.), vacated on other grounds, 444 U.S. 996 (1979) (plurality opinion holding that case was nonjusticiable under political question doctrine).

Even Madison subsequently adopted Hamilton's view when, as President, in a model of paramilitary covert action, he sent agents to destabilize East and West Florida in preparation for a congressionally unauthorized military force to gain U.S. control, despite peaceful relations between the U.S. and Spain. See A. SofaER, WAR, ForeigN Affairs ANd Constitutional Power 264-65, 291-317 (1976).

${ }^{88}$ See Covert Hearings, supra note 22, at 248-49 (memorandum for the Attorney General on the President's constitutional powers with respect to intelligence activities). Special activities "are among the most sensitive and vital aspects of the President's constitutional responsibilities in the field of foreign relations," and they "lie[] at the very heart of the President's executive power." See Statement of Assistant Attorney General Charles Cooper, Before the Senate Select Comm. on Intelligence, on S. 1721, December 11, 1987 at 6 (on file with the University of Pennsylvania Law Review).

The Congress has a somewhat different interpretation. "With repsect [sic] to the Executive, this authority [in the area of national security] flows from his responsibility as Commander-in-chief and from the power to make treaties and appoint ambassadors. The authority of the Executive to conduct intelligence activities, including special activities, has been implied as a necessary extension of these responsibilities." S. REP. No. 276 , supra note 28 , at 20 .

The difference between these two interpretations is not insignificant. The refusal to accept an expansive reading of the Executive clause is to be expected, since the ramifications for reducing or eliminating congressional powers in a variety of fields would be enormous. Conversely, by arguing that the President's authority with respect 
the presidency first set forth by Theodore Roosevelt, ${ }^{99}$ the claim is made that the executive power is circumscribed only by limits expressly contained in the Constitution itself, and "such statutory limitations as the Constitution permits Congress to impose by exercising one of its enumerated powers. The President's executive power includes, at a minimum, all the discretion traditionally available to any sovereign in its external relations, except insofar as the Constitution places that discretion in another branch of the government."100

It follows that if the Executive has such broad and sweeping powers over foreign affairs, then intelligence activities are at the core of this grant since they are necessary for the formulation of foreign policy and the safeguarding the country from surprise attack. ${ }^{101}$

This conclusion comports with Hamilton's view of the need to provide for unforeseeable exigencies that would require energy, secrecy, and dispatch in the Executive Branch. ${ }^{102}$ John Jay even went so far as to explicitly link intelligence activity with the President's need to operate with secrecy and dispatch.

It seldom happens in the negociation of treaties of whatever nature, but that perfect secrecy and immediate dispatch are sometimes requisite. There are cases where the most useful intelligence may be obtained, if the persons possessing it can be relieved from apprehensions of discovery. Those apprehensions will operate on those persons whether they are actuated by mercenary or friendly motives and there doubtless are many of both descriptions, who would rely on the secrecy of the president, but who would not confide in that of the senate, and still less in that of a large popular assembly. The convention have [sic] done well therefore in so disposing of

to intelligence activities derives solely from the Commander-in-Chief and treaty clauses, Congress's role in intelligence matters is greatly enhanced. Specifically, such an approach, while suggesting collection activities are closer to an Executive function leaves congress authority and responsibilities for covert action. The President can command only those forces authorized by Congress, and can make treaties only with the advise and consent of the Senate. This would imply a great congressional role in regulating special activities. See id. at 20-21; infra notes 120-24 and accompanying text.

89 Roosevelt argued that the brevity of powers explicitly granted to the presidency in the Constitution was meant to reserve to the President all powers not explicitly granted to Congress by the Constitution or by constitutionally permissible legislation. See T. Roosevelt, Theodore Roosevelt; AN Autobiography 394-97, 504 (1913).

${ }_{100}$ Covert Hearings, supra note 22, at 249.

101 The Court has not explicitly endorsed a similar view of the relationship between intelligence activities and the president's foreign affairs powers but has used language not too removed from this position. See infra notes 104-08.

${ }_{102}$ See The Federalist No. 70, at 471-72 (A. Hamilton) (J. Gooke ed. 1961). 
the power of making treaties, that although the president must in forming them act by the advice and consent of the senate, yet he will be able to manage the business of intelligence in such manner as prudence may suggest. ${ }^{103}$

\section{The Court's Interpretation of the Dispute}

The Supreme Court has over the years also recognized some presidential plenary power to conduct foreign affairs. In United States $v$. Curtiss-Wright Export Corp., ${ }^{104}$ Justice Sutherland, writing for the Court, noted the existence of "very delicate, plenary and exclusive power of the President as the sole organ of the federal government in the field of international relations-a power that does not require as a basis for its exercise an act of Congress . . ."105 Justice Sutherland, himself a former senator, understood the meaning of granting the President status as the country's sole organ in foreign affairs. Sutherland

${ }^{103}$ Id. No. 64, at 434-35 (J. Jay) (emphasis added).

104299 U.S. 304 (1936). Curtiss-Wright is frequently misread by those who wish to minimize the President's foreign affairs power. The case is often interpreted as an affirmation of congressional powers because the Court upheld a joint resolution supporting the President's prohibition of weapon sales to a South American war zone. Viewed in this way, the Court's treatment of the President's foreign affairs powers is reduced to dicta and therefore has no precedential value. See L. Fisher, supra note 22, at 5-8 (noting that Curtiss-Wright is really an affirmation of congressional power and that Sutherland's language is irrelevant dicta); $c f$. Covert Hearings, supra note 22, at 281 (arguing for congressional right to prior notice despite "judicial dicta regarding inherent presidential authority in foreign affairs"). The actual issue involved, however, was an excessive delegation of congressional powers. See Curtiss-Wright, 299 U.S. at 315. The New Deal era saw the Court strike down several congressional actions for excessive delegation. The congressional resolution in question before the Court was like those struck down earlier: broad and vague. To uphold this action, the Curtiss-Wright Court focused on the difference between presidential domestic and foreign affairs powers.

The Court essentially realized that the statute clarified any confusion of the President's authority to enforce the embargo within the country. The Court thus adopted a bifurcated analysis of congressional and presidential powers, with different scope and reach in domestic and foreign affairs. Thus, the Court's treatment of the President's foreign affairs powers is crucial to the Court's holding. This case should be properly read as affirming presidential powers in foreign affairs-independent of the Congress.

105 Curtiss-Wright, 299 U.S. at 320; see also Chicago \& S. Air Lines v. Waterman Steamship Corp., 333 U.S. 103, 109 (1948) (referring to the President as the "Nation's organ" in the realm of foreign affairs). The notion of the President as the "sole organ" in the field of foreign affairs reaches back to Hamilton and his Federalist Paper writings. See The Federalist, supra note 102, No. 74, at 505 (A. Hamilton) ("The qualities elsewhere detailed, as indispensible in the management of foreign negotiations, point out the executive as the most fit agent in those transactions."); see also Curtiss-Wright, 299 U.S. at 319 (quoting address by John Marshall to the House of Representatives on March 7, 1800, in which he said that the "President is the sole organ of the nation in its external relations, and its sole representative with foreign nations"). 
added:

It is quite apparent that if, in the maintenance of our international relations, embarrassment-perhaps serious embarrassment-is to be avoided and success for our aims achieved, congressional legislation which is to be made effective through negotiation and inquiry within the international field must often accord to the President a degree of discretion and freedom from statutory restriction that would not be admissible were domestic affairs alone involved. Moreover, he, not Congress, has the better opportunity of knowing the conditions that prevail in foreign countries, and especially is true in time of war. He has his confidential sources of information. He has his agents in the form of diplomatic consular and other officials. Secrecy in respect of information gathered by them may be highly necessary, and the premature disclosure of it productive of harmful results. ${ }^{106}$

The basic dichotomy between domestic and foreign affairs powers of the President and Congress that relies upon the President's role as the nation's sole organ has not been repudiated. ${ }^{107}$ Naturally, Congress is not foreclosed from all regulation of foreign affairs, and certainly it is entitled to receive information about the Executive's conduct in that field. ${ }^{108}$ The question remains, however, how far may Congress extend its oversight powers before it poses an unconstitutional interference

${ }^{108}$ Curtiss-Wright, 299 U.S. at 320.

${ }_{107}$ See, e.g., Dames \& Moore v. Regan, 453 U.S. 654 (1981) (citing Justice Sutherland's language in Curtiss-Wright).

${ }^{108}$ See supra notes 71-91 and accompanying text. When the secrecy of foreign affairs information sought by Congress is deemed vital to the national security, the President may refuse to provide Congress with the information, claiming that the material is subject to executive privilege. Decisional authority has established the President's power to determine the extent of the need to maintain the secrecy of material touching on areas of national security and foreign policy. In United States v. Nixon, 418 U.S. $683(1974)$, the Court for the first time addressed the issue of executive privilege in the context of an interbranch dispute. It rejected the President's claim of absolute immunity to withhold information based on that privilege. See id. at 706 (noting that there is not "an absolute, unqualified Presidential Privilege"). The Court recognized that "[n]owhere in the Constitution ... is there any explicit reference to a privilege of confidentiality, yet to the extent this interest relates to the effective discharge of a President's powers, it is constitutionally based." Id. at 711. Nevertheless, the Court adopted the Curtiss-Wright bifurcated approach: with regard to domestic matters, the extent of privilege is limited. For example, in a criminal context, the extent of executive privilege is narrow and must yield to the "right to the production of all evidence at a criminal trial [which also has] constitutional dimensions." Id. at 711. In the context of foreign affairs, the Court recognized a broad "claim of need to protect military, diplomatic, or sensitive national security secrets," $i d$. at 706 , to which the judiciary has "traditionally shown the utmost deference to Presidential responsibilities." Id. at 710 . 
with the Executive's discretion over foreign affairs?

Given this claim of plenary and exclusive executive powers in the field of foreign affairs and intelligence activities in particular, any congressional attempts to restrict or interfere with executive discretion in intelligence activities are seen as an infringement on executive power. As members of the Executive Branch testified before the Senate Select Committee on Intelligence:

[T]here may be instances where the President must be able to initiate, direct, and control extremely sensitive national security activities. We believe this presidential authority is protected by the Constitution, and that by purporting to oblige the President, under any and all circumstances, to notify Congress of a covert action within a fixed time, [the proposed legislation] infringes on this constitutional prerogative of the President . . . . A President is not free to communicate information to Congress if to do so would impair his ability to execute his own constitutional duties. Under some circumstances, communicating findings to Congress within [a prescribed time limit] could well frustrate the President's ability to discharge those duties. ${ }^{108}$

\section{B. Balancing Oversight Against Intelligence: How Far May Congress Go?}

\section{Two Tests for Violations of Separation of Powers}

There are two general approaches to determining whether a particular statute offends the doctrine of separation of powers. The first line of analysis, followed in Morrison v. Olson, ${ }^{110}$ Nixon v. Administrator of General Services, ${ }^{111}$ and Commodity Futures Trading Commission v. Schor, ${ }^{112}$ dictates that when the statute in question does not increase the power of one branch at the expense of another, the court must determine whether the law "impermissibly interfer[es] with" the performance of the constitutional functions of the other branch. ${ }^{113}$ If the court finds such an impermissible interference, then a balancing test

109 S. REP. No. 276, supra note 28, at 19-20 (testimony of Assistant Attorney General Charles Cooper) (emphasis added); see infra text accompanying notes 136-41 (giving an example of one such circumstance that compelled DCI Turner to withhold congressional notification in the interests of national security and preservation of life).

110108 S. Ct. 2597, 2620-21 (1988).

11433 U.S. 425,443 (1977).

112478 U.S. $833,851-58$ (1986).

113 Morrison, 108 S. Ct. at 2622. 
may be necessary to weigh the interests furthered by the statute against the burden placed upon the other branch. ${ }^{114}$

The second test, enunciated in Immigration \& Naturalization Service v. Chadha ${ }^{115}$ and Bowsher v. Synar, ${ }^{116}$ is based upon formalistic notions of separation of powers analysis and forbids one branch from usurping the power or responsibilities of another branch. ${ }^{117}$ For example, in Chadha, the Court held that Congress may not take action that has the purpose or effect of "altering the legal rights, duties, and relations of persons" outside the Legislative Branch unless the constitutional mechanisms for passing laws are observed. ${ }^{118}$ Similarly, in Bowsher, the Court stated that it is unconstitutional for an agent of Congress "to be entrusted with executive powers."119

In the case of congressional oversight provisions designed to give Congress information about the Executive's intelligence activities, the proper approach is functional balancing, i.e., to ask whether the oversight mechanism impermissibly interferes with the Executive's conduct of intelligence activity. It is evident from the language of the $1980 \mathrm{In}$ telligence Oversight Act, as well as the several proposals to modify the oversight mechanism, ${ }^{120}$ that Congress is seeking to enforce its right to receive information. At the same time, the Act of 1980 reflects the efforts of the Congress to avoid any explicit encroachment upon executive

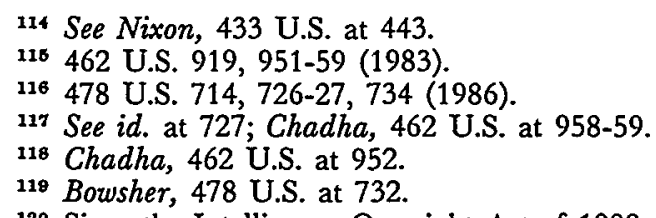

120 Since the Intelligence Oversight Act of 1980, Pub. L. No. 96-450, § 501, 94 Stat. 1975, 1981-82 (codified at 50 U.S.C. $\S 413$ (1982)), Congress has recognized the Executive's ability to initiate special activities without prior notice. Nonetheless, Congress has placed limits on executive nondisclosure. See 126 CoNG. REc. 13,125 (1980) (statement of Sen. Huddleston) ("Section 501(b) [of the Oversight Act of 1980] recognizes that the President may assert constitutional authority to withhold prior notice of covert operations ...."). Congress also placed limits on how long the President may withhold notice.

The President shall fully inform the intelligence committees in a timely fashion of intelligence operations in foreign countries, other than activities intended solely for obtaining necessary intelligence, for which prior notice was not given under subsection (a) and shall provide a statement of the reasons for not giving prior notice.

Intelligence Oversight Act of 1980, Pub. L. No. 96-450, § 501(b), 94 Stat. 1975, 1982 (codified at 50 U.S.C. $\S 413(\mathrm{~b})(1982)$ ).

Reform proposals have removed the vague "timely fashion" requirement and substituted a clear-cut 48-hour provision. See, e.g, H.R. 3822, 100th Cong., 1st Sess. (1987) (written findings to be reported to Congress within 48 hours). This recommendation apparently is a by-product of the Iran-Contra affair. See IRAN-ConTRA REPORT, supra note 3 , at 423 (recommending a requirement that the President notify Congress no later than 48 hours after approving a finding for covert action). 
power. ${ }^{121}$ Since Congress has publicly claimed that oversight in general, and prior notice in particular, are designed merely for informational and consultative purposes ${ }^{122}$ and do not involve approval or permission, ${ }^{123}$ oversight does not usurp the Executive's mission or constitutional prerogatives. ${ }^{124}$

The question thus becomes whether the notice requirements impermissibly interfere with the President's ability to conduct intelligence activity. As this Comment demonstrates below, the language requiring prior notice-or allowing after-the-fact notice only within a rigid timeframe ${ }^{125}$-impermissibly interferes with the President's power to conduct intelligence activity, and is therefore unconstitutional.

\section{Congressional Oversight as Impermissible Interference}

Under the incidental effects test followed in Morrison, Schor, and Nixon, the constitutionality of prior notice requirements, or defined statutory time limits for after-the-fact notice, turns on whether such a scheme "impermissibly undermine[s]" the power of the Executive Branch, or 'disrupts the proper balance between the coordinate branches [by] prevent[ing] the Executive Branch from accomplishing its constitutionally assigned functions.' "126

\section{a. The Confidential Nature of Intelligence Activity}

The executive functions affected by Congressional intelligence oversight measures are extremely sensitive to publicity. In performing

121 See Intelligence Oversight Act of 1980 , Pub. L. No. 96-450, § 501, 94 Stat. $1975,1981-82$ (codified at 50 U.S.C. $\S 413$ (1982)). The Act contains the significant language specifying that notice requirements apply only " $[t]$ o the extent consistent with all applicable authorities and duties, including those conferred by the Constitution upon the executive and legislative branches of the Government" and recognizing that there may be instances when prior notice is not given. See id. § 501(a), (b).

122 But see supra note 14 (describing congressional leaks of classified intelligence activities); infra notes 163-64 and accompanying text (same).

${ }_{123}$ See Intelligence Oversight Act of 1980 , Pub. L. No. 96-450, \& 501 (a)(1), 94 Stat. 1975, 1981 (codified at 50 U.S.C. $\S 413(\mathrm{a})(1)$ (1982)) ("[T] shall not require approval of the intelligence committees as a condition precedent to the initiation of any such anticipated intelligence activity ... ."); S. 1721, 100th Cong., 2d Sess. (1988) (seeking to amend the Oversight Act of 1980 to provide that "nothing contained in this title shall be construed as requiring the approval of the intelligence committees as a condition precedent to the initiation of [intelligence] activities"); H.R. 3822, 100th Cong., 1st Sess. (1987) (same).

124 See S. REP. No. 276, supra note 28 , at 24.

125 The time limit is forty eight hours in S. 1721 and H.R. 3822. See S. 1721, 100th Cong., 2d Sess. (1988) (amending $\S 503(\mathrm{a})(1)$ of the Act); H.R. 3822, 100th Cong., 1st Sess. (1987) (same). 443).

${ }_{128}$ Morrison, 108 S. Ct. at 2621 (footnotes omitted) (quoting Nixon, 433 U.S. at 
the Executive's intelligence functions, intelligence agencies constantly deal with information that must remain confidential in order to prevent harm to the security and safety of the nation, its allies, and individuals whose lives are at risk because of intelligence operations. The Court, recognizing the importance of this responsibility, has acknowledged the Executive's substantial latitude in the conduct of foreign affairs. ${ }^{127}$ The Executive's control over confidential information relating to national security is also interpreted broadly. ${ }^{128}$

Congressional requirements for prior notice impermissibly interfere with the President's ability, and indeed his obligation, to safeguard and preserve confidential national security information. "Prior reporting would reduce the president's flexibility to deal with situations involving grave danger to personal safety, or which dictate special requirements for speed and secrecy."129 Legislation imposing a rigid timetable for after-the-fact notification would be equally burdensome.

In Morrison, the Court concluded that there was no impermissible interference with the Executive under an incidental effects test because "the [Ethics in Government] Act does give the Attorney General several means of supervising or controlling the prosecutorial powers" of the independent counsel. ${ }^{130}$ The Court decided that "these features of the Act give the Executive branch sufficient control . . . to insure that the President is able to perform his constitutionally assigned duties," while noting that such a prosecutor has greater freedom from executive supervision than other prosecutors. ${ }^{131}$ Thus, the central basis for the Court's decision to uphold the Ethics Act in Morrison was the legislation's minimal interference with an inherent executive power. ${ }^{\mathbf{1 3 2}}$

The intelligence function is also an inherent power, ${ }^{133}$ but the interference caused by rigid notice requirements is much greater than the interference in Morrison. Under the proposed oversight legislation, ${ }^{134}$

127 See supra notes 104-08 and accompanying text.

${ }^{128}$ See supra note 108.

129 National Intelligence Act of 1980: Hearings before the Senate Select Comm. on Intelligence, 96th Cong., 2d Sess. 17 (1980) (prepared Statement of Admiral Stansfield Turner).

130 Morrison, 108 S. Ct. at 2621.

131 Id. at 2622.

132 Similarly, in Schor, the Court held that initial administrative adjudication of claims and counterclaims under the Commodity Exchange Act did not "impermissibly undermin[e]" the powers of the judiciary, Schor, 478 U.S. at 856-57, and in Nixon, it approved an act directing the Administrator of General Services to take control of Nixon's papers, and preside over their dissemination, finding that this did not prevent "the Executive Branch from accomplishing its constitutionally assigned functions." Nixon, 433 U.S. at 443.

1s3 See supra notes 103-09 and accompanying text; supra note 121.

134 See supra note 12. 
the Executive Branch surrenders necessary flexibility in the intelligence field to withhold prior notice or notice beyond the fixed time frame on the basis of national interest. While the legislation, on its face, disavows any prior approval of executive action, the existence of stringent reporting requirements necessarily impairs the President's plenary authority to exercise his role as the nation's sole organ in foreign affairs. This is tantamount to approval of only those operations that can be safely communicated to Congress within the legislatively imposed time frame. There will almost certainly be some highly sensitive operations and activities that the President will determine to be in the national interest, and such provisions will render these operations infeasible by preventing the Executive branch from acting with "secrecy and dispatch."

\section{b. The "Canadian Caper"}

A recent historical example demonstrates the magnitude of congressional interference and serves to illustrate the practical implications of this debate. In 1979, Iranian students seized fifty-two hostages in the American embassy in Tehran. Unknown to the Iranians, and the rest of the world, six other Americans were hidden at the Canadian embassy. ${ }^{135}$ The Canadian government agreed to hide the Americans until a covert exfiltration operation could be organized to ensure their safe passage out of Iran, but only on the express condition that the President allow access to the information on a strict "need-to-know" basis, and refuse to notify Congress. ${ }^{136}$ The Canadians feared that a leak would result in the seizure of their embassy.

The rescue operation took three months to organize and carry out and the six Americans were safely returned home. ${ }^{137}$ Congress was informed-but only after the operation had extricated the Americans from Iran. In order to save American lives and honor the pledge given to Canada, Admiral Turner and President Carter postponed notification of the eight congressional committees until the rescue mission was

135 See Covert Hearings, supra note 22, at 46.

${ }^{136}$ See Oversight Legislation, 1987: Hearings on S. 1721 and S. 1818 Before the Senate Select Comm. on Intelligence, 100 Cong., 2d Sess. 209 (1988) [hereinafter Hearings] (testimony of Secretary of Defense Frank Carlucci, former DDCI under Stansfield Turner) ("[T]he Canadians indicated that if the Congress was to be informed, they wouldn't cooperate."). Senator Jim McClure has also stated that "[t]he Canadians said they would not help unless the administration promised not to notify Congress." See McClure, A 48-Hour Rule For Covert Operations? No, Wash. Post, Sept. 26,1988, at A11 col. 5. Admiral Turner, however, has stated that "I don't really recall that clearly." Telephone Interview with Stansfield Turner, former DCI (Oct. 7, 1988).

137 See Covert Hearings, supra note 22, at 61. 
successfully completed. ${ }^{138}$ In doing so, however, they violated the Hughes-Ryan Act, which required notification to the eight committees of Congress about the covert action. ${ }^{139}$

This so-called "Canadian Caper" demonstrates how an unconditional statutory requirement to inform Congress within a fixed period of time can interfere with the Executive's conduct of his foreign affairs power. The time required for necessary preparations could not have been dictated or even predicted; the mission could not have been undertaken if the short, rigid notification provision had not been violated. In fact, in Iran the CIA did not even have any assets in place; one operative, code-named "Bob," had to be coaxed out of retirement to start building an exfiltration network in Iran from scratch. ${ }^{140}$ Operatives that entered Iran did so on several occasions to reconnoiter the scene, and the information they retrieved had to be evaluated extensively. Only after all this was completed, could the placement of operatives into Tehran to assist the exfiltration begin-a process that involved grave personal risks to the operatives and those Iranians who assisted them. Once the operatives were in place, it remained impossible to impose a strict timetable that would permit a low-risk notification to Congress. Had the President notified Congress within the statutory time period, he would not have been able to justify undertaking the rescue operation.

In the "Ganadian Caper" case, the burden not to divulge the operation was placed on the President by a foreign power. While the same problem regarding life or the need for total secrecy can arise out of strictly domestic concerns, the action by the Canadian government should not be seen as a unique event. The Executive branch constantly interacts with foreign states that are leery of surrendering secrets or

198 See Hearings, supra note 136, at 220. Carlucci stated, "Now we did inform after the fact." He added, however, "I was one of the decision-makers [to withhold notification to Congress] and I would not have [given prior notice], in retrospect. Because I think those people would still be there had we not agreed to withhold information." Id.

${ }^{138}$ See The Hughes-Ryan Amendment, Pub. L. No. 93-559, § 662, 88 Stat. 1795, 1804 (1974) (requiring "timely notice" to the appropriate committees of Congress), amended by The Intelligence Oversight Act of 1980, Pub. L. No. 96-450, $\S 407$ (a), 94 Stat. 1975, 1981 (incorporating id. $\S 501,94$ Stat. at 1981-82 (codified at 50 U.S.C. $\S 413(1982))$ ). The 1980 Act requires prior notice as a general rule, and requires that the appropriate committees of both houses be informed in a "timely fashion" when prior notice is not given. See Covert Hearings, supra note 22, at 1-2 (opening statement of Rep. Matthew F. McHugh); supra notes 62-64, 120-21 and accompanying text.

140 See J. RANELAGH, supra note 13, at 652, 655 (noting that an exfiltration network is not the same as a general collection network; the former is specialized and must remain ad-hoc to keep it from getting rolled up by local counterintelligence). 
confidences. ${ }^{141}$ Foreign powers or operatives, knowing that participation with the United States in a special activity requires rigid congressional notification procedures, may well refuse to extend their assistance. ${ }^{142}$ In this way, rigid notification requirements interfere with the President's ability to conduct foreign affairs, since they deny him the ability to receive such assistance. This legislation thus "impermissibly undermine[s]" the powers of the executive branch ${ }^{143}$ and "prevents the Executive Branch from accomplishing its constitutionally assigned functions." ${ }^{144}$ While the legislation may on its face disavow any prior approval of executive action, the existence of the statute will necessarily impair the President's plenary capacity to exercise his role as the nation's "sole organ" in foreign affairs. This is tantamount to an a priori congressional approval of only those operations that can be communicated to Congress within the legislatively imposed time frame.

The above analysis does not reject the premise that Congress has a right to receive information about intelligence activity. The intelligence oversight dispute centers ${ }^{145}$ on when Congress is entitled to receive such information. The intelligence process requires flexibility between the two branches in order to safeguard the President's prerogatives and the nation's security.

The result may be that Congress will not receive information until after the fact-as in the "Canadian Caper." Congress will likely find this inconvenient for some of its oversight desires. ${ }^{146}$ But, as the Court stated in Bowsher, "the fact that a given law or procedure is efficient,

141 See Hearings, supra note 136, at 212-213 (statement of former DDCI and Secretary of Defense Frank Carlucci). "I don't know how many times when I was in the CIA cooperating intelligence organizations expressed their concern on this subject. Certainly it was numerous. They will frequently tell you that we will give you this information providing it does not go to your Congress." Id. According to Carlucci, this is because the U.S. deals with nations that "don"t always understand our institutions, that have different institutions of their own. . . . and are basically mistrustful of the dissemination of information beyond the Executive branch." Id. at 217; cf. supra note 103 and accompanying text (argument by John Jay that some may trust the President to keep secrets, but are less likely to trust the Senate, and even less so the House).

${ }_{162}$ See National Intelligence Act of 1980: Hearings on S. 2284 Before the Senate Select Comm. on Intelligence, 96th Cong., 2d Sess. 25 (1980) (testimony of Admiral Stansfield Turner); see also Hearings, supra note 136, at 201. According to Secretary of Defense Carlucci, a former chief of West German intelligence stated that proposed oversight legislation "would prevent any allied intelligence service rendering any assistance to the United States on covert action." Id. Former DDCI and DDO John McMahon has also stated "that a number of nations would refrain from supporting us for fear that their association might become public." Id. at 246.

143 Schor, 478 U.S. at 856.

144 Nixon, 433 U.S. at 443.

145 See supra notes $39-58$ and accompanying text.

${ }^{146}$ See supra notes 50-56 and accompanying text (argument by the Senate that legislative oversight requires knowledge of all special activity). 
convenient, and useful in facilitating functions of government, standing alone, will not save it if it is contrary to the Constitution. Convenience and efficiency are not the primary objectives-or the hallmarks-of democratic government ...."147

The conclusion that rigid notification requirements impermissibly interfere with executive functions does not end the constitutional analysis. Once an impermissible interference is found, the interests furthered by the statute must be weighed against the burden placed on the Executive. ${ }^{148}$ Thus, Congress's right to be informed immediately must be weighed against the Executive's interest in the activity in question.

\section{A Functional Balancing Test}

This Comment proposes that a balancing test must be used to examine each case in a functional manner. As demonstrated above, Congress's constitutional right to inflexibly demand information is somewhat qualified in the intelligence area. ${ }^{148}$ Congress should be given wider latitude, however, with respect to activities that are closer to the related penumbra of congressional grants of power.

The clearest case for a congressional right for statutorily defined notice is the case of a paramilitary operation, such as Operation White Star in Indochina or the Contras in Honduras. A functional balancing test would weigh on one side, the strong congressional interests in (1) whether a state of war might result; (2) the impact on the Army and Navy-in terms of both personnel and equipment; and (3) whether laws were or are being violated. ${ }^{150}$ These concerns would then be balanced against the Executive's interest in secrecy, dispatch, and his ability to conduct foreign affairs. ${ }^{151}$ While a strict requirement of prior notice or timely notice after the fact might interfere with the Executive, a balancing of interests would probably conclude that such a requirement would be constitutional. The Executive could initiate action without fear of hinderance and would maintain both secrecy and dispatch. Congress's oversight interests would also be met.

Application of a functional balancing test to other types of special activity does not result in similar outcomes. For example, consider an exfiltration situation similar to the Canadian case. Applying the same

147 Bowsher, 478 U.S. at 736 (quoting Chadha, 462 U.S. at 944).

${ }^{148}$ See Schor, 478 U.S. at 856; Nixon, 433 U.S. at 443.

149 But cf. Covert Hearings, supra note 22, at 191 (statement by Rep. Shuster that Congress has a "right to have . . certain information" (emphasis added)). ing text.

${ }_{100}$ See S. REP. No. 276 , supra note 28 , at 21 ; supra notes 36-51 and accompany-

151 See supra notes $92-103$ and accompanying text. 
notice requirements invokes the same congressional interests, such as investigating that laws were not broken, a state of war might result, or the impact on the armed forces. Yet, in the balance, in an exfiltration situation, these same congressional interests are not as pressing and thus weigh less in the scale when compared to the Executive's interests. Congressional concerns do not require prior notice or some arbitrarily defined time period. Given the Court's precedent giving "the utmost deference" to the Presidency in the sphere of national security, ${ }^{162}$ the same notification requirements that would be constitutional in a paramilitary situation are an unconstitutional interference in an exfiltration episode.

A separate, hypothetical, example might help clarify the distinction further. As described earlier, special activity can include the covert rendering of assistance to foreign labor movements or newspapers. ${ }^{153}$ Consider pre-martial law Poland. The U.S. has a HUMINT asset serving within the Polish security services in a collection mode. Learning of a possible impending crack-down by the Polish government from this source, his U.S. control directs the asset to participate in the decisionmaking process either to deflect a decision towards U.S. aims or gain time to facilitate covert American financial or technical assistance to Solidarity. Technically, this HUMINT asset has now become part of a special activity, yet the exact time when the operation commences becomes ambiguous. When does Congress need to know? When the plan is conceived? When his orders are transmitted (and given the vagaries of tradecraft, who knows when received)? Once his participation begins? The same type of balancing test would weigh congressional interests and the relevant congressional constitutional powers, with the presidential need to move with speed and stealth. Again, the same congressional interests and powers invoked in the paramilitary example do not support the assertion that Congress must be informed about this operation within a statutorily defined time period. This is particularly so when the cooperation of foreign powers or assets, eager to remain anonymous (at least until the operation is over), is contingent on nonnotification.

As an interesting observation, this use of a functional balancing test also argues against congressional imposition of notice requirements in the area of clandestine collection. ${ }^{154}$ This is true not only in the area

162 See United States v. Nixon, 418 U.S. 683, 710 (1974).

153 See supra notes 27-28 and accompanying text.

154 Congress has not sought to include collection efforts within its various timely notice schemes. In fact, both the 1980 Oversight Act and current reforms all mention that they do not apply to "necessary collection". See 50 U.S.C. $\S 413($ a)(1)(A) (1982). 
of HUMINT operations, when the risk to human life and foreign cooperation is clear, but also in the direction of "national technical means" and other ELINT/SIGINT assets, when potential targets, if alerted, may change their posture to frustrate the intended collection effort. Proponents of congressional oversight so far have not sought to impose restrictions on collection, but refrain from doing so by strictly linking collection activities to direct grants of presidential power, the naming of ambassadors and the receiving of foreign diplomats. ${ }^{155}$ Congressional proponents will be opposed to the use of a functional test, for though it supports the same conclusion with respect to collection, it defeats the purpose of their ingenious argument-to limit presidential power by strictly construing Article II and conversely giving Article I a broad reading concerning special activity.

The proposed functional balancing test is not a legal fiction designed to shield the Executive from congressional scrutiny. The test, as proposed, does not deny the necessity or legality of congressional oversight, for Congress must be notified of the activity. The argument is that legislation such as S. 1721 or H.R. 3822 is unconstitutional because it does not permit flexibility based on a discrete functional analysis, but demands prior notice or notification within a fixed time period for all special activities. This legislation treats all special activity as if it were the constitutional and legal equivalent of paramilitary activity.

Recently, Congress has begun to assert strongly its oversight powers. In this and the previous Section, the constitutional limits on Congress's rights to demand information have been defined, while also articulating when and why the Executive has a right to withhold information. Part Three proposes a compromise solution within the legal extremes discussed previously. This proposal protects the President's constitutional role, yet also preserves Congress's legitimate need to oversee the intelligence process for appropriations and to ensure that laws are not being violated. Changes in the Intelligence Oversight Act will permit Congress to monitor Executive Branch activity in order to prevent circumstances similar to the Iran-Contra incident, while preserving the Executive's secrecy and dispatch.

185 See, e.g., S. REP. No. 276, supra note 28, at 20 (accepting "the view that where the Constitution gives the President independent and exclusive authority to act-for example, the power to 'receive ambassadors and other public ministers'-Congress cannot deny him . . . from carrying out such activities"); Covert Hearings, supra note 22, at 219-220 (letter by Louis Henkin explaining why collection activities are different from special activity with respect to congressional oversight); see also supra note 98. 


\section{A More Intelligent ApProach to INTEli.igence OVERSIGHT}

\section{A. Policy and Compromise}

So far, this Comment has focused on the constitutionality of various intelligence oversight mechanisms. But the revelation that rigid time-notification requirements will often violate the doctrine of separation of powers does little to guide policymakers in their formulation of a legal and effective oversight mechanism. Reconciling the current approach to oversight with the need to preserve flexibility requires compromise from both the Executive and Legislative Branches. Such an approach, emphasizing the need for cooperation, will accommodate the various institutional interests of the Congress, the Executive, and the intelligence community. ${ }^{156}$

In order to improve intelligence oversight while enhancing the quality of intelligence activity in the field, an approach must be both accountable and flexible. The 1980 Oversight Act was helpful, but little more than a step in the right direction. Staid legal rigidity that threatens the system with gridlock and breakdown must be eliminated and reformation of the process pursued along a twin-track: (1) changes in the statutory basis for oversight and (2) modifications in the oversight structure itself.

\section{A Sliding Scale of Risk}

The current trend toward ossification of oversight into discrete, discernable, but unrealistic legal categories of "timeliness," is not only unconstitutional but impracticable. Instead of seeking to create ironclad notice requirements, Congress can preserve the constitutionality of its oversight legislation and insure performance by seeking a flexible standard that prevents the abuses associated with non-accountability while preserving the operational effectiveness of the intelligence community.

An acceptable solution requires Congress to recognize that, by nature, intelligence operations entail risk. Adoption of a notice standard based on a graduated scale of risk would provide the necessary flexibility for oversight while preserving the Executive's inherent and plenary

${ }^{186}$ Cf. Covert Hearings, supra note 22, at 45 (statement of former DCI Turner, noting that "good will and cooperation between the Executive Branch and the two congressional committees on intelligence may be more important than written agreements or provisions of law"). 
powers in the realm of foreign affairs. ${ }^{\mathbf{1 6 7}}$

The mechanism is simple. Under a sliding scale procedure, the President notifies Congress of the initiation of a covert operation (just as in existing legislation and proposed reforms) with a Memorandum of Notification ("MON"). The President, however, states in the MON that the details of the operation cannot yet be divulged. ${ }^{158}$ Instead, he invokes the procedure to define timeliness based on risk. The docket at the Senate and House Select Committees on Intelligence would register the MON, but, unlike other special activities that have their own program element ("PE") funding, approved by the intelligence committees, this MON would use the congressionally created and authorized DCI contingency fund. As a means of preventing the Executive from misusing this device-for example, by initiating covert paramilitary action without adequate notice to Congress-the funds available for such a MON could be limited either by the total dollar amounts available or by the number of drawdowns permitted for a single operation. Once the risk was judged to be sufficiently reduced, the Executive would file a supplementary explanation giving the reason for withholding notification and giving an accounting for the funds expended.

To use the example discussed earlier, under this scheme, in a scenario similar to the "Canadian Caper," the DCI would file a MON with Congress, notifying it of the commencement of the operation. $\mathrm{He}$ would not mention the target country, the nature of the operation (in

${ }^{157}$ See Covert Hearings, supra note 22, at 58. Former DCI Turner stated:

[T]imeliness is not measured by a clock. Timeliness should be measured by the risk. ... .

So I don't think we should focus on hours and days. I think we should focus on diminution of the risk. It could be that as an operation goes along the risk to human life drops off but the operation under the Finding is still continuing. That would be the point at which the Executive should come to Congress. When that risk to human life is diminished sufficiently is when it is timely to notify the Congress in my opinion, sir.

Id. Former DCI Colby has argued that even non-life-threating situations may also be valid reasons for withholding Congressional notice. See id. at 59.

${ }_{158} C f$. id. at 145 (statement by Lloyd Cutler) (noting that the DCI would be asked about the operation by the committee every time he appeared for funds and required to give reasons for denying details to Congress).

This compromise proposal has the attraction of giving Congress prior notice but addressing some of the security qualms advanced by the intelligence community. According to Cutler,

[T] hen after time, the DCI comes up to testify, you will be asking him what was that operation, and why can't you tell us? Sooner or later, as long as you know that something is happening, eventually you will find out and it is the finding out and requiring him to account $I$ think is more powerful than the consultation earlier.

Id. at 149 . 
this case exfiltration), or the number of persons involved. The DGI's Contingency Fund drawdowns for an operation of this sort would not approach the level necessary to train, equip, and supervise an army in the jungles of Laos or Honduras. After the hostages were safe from harm, the DGI would then file a supplementary MON providing the details of the operation and explaining the request of the foreign government (but not necessarily giving the actual country's name) and the risk both to human operatives and the hostages themselves. An appendix with the accounting of funds would complete the process. Should Congress believe the risk mechanism was abused, it could then legislate changes in access to the contingency fund to prevent similar operations from using the risk mechanism. ${ }^{159}$

It should be emphasized that the use of a scale of risk is based on the premise that only the most pressing circumstances would warrant its use. Congress is today already receiving prior notice of the vast majority of intelligence operations. ${ }^{100}$ A notice requirement based upon a sliding scale of risk would not give the DGI carte-blanche authority to abuse appropriations. First, restrictions on the DGI's contingency fund ensure some control over scale and operational objectives. Given these financial reins and the realities of modern reporting-which make sustained paramilitary programs almost impossible to hide from the public eye-Congress would know from the start that the sliding scale process would be limited to the most discrete operations. ${ }^{161}$ Furthermore, once the level of risk is reduced, Congress can demand a full accounting of expenditures, or if need be, raise the issue to the political fora for debate with the Executive. In response to any improper use of the sliding scale mechanism, Congress can always pass restrictive legislation simi-

150 Stansfield Turner is opposed to the idea of placing limits on the DCI's access to the contingency fund in cases in which risk prevents notification. "I wouldn't want to limit a DCI by this kind of scheme. There seems to be no sense in going in by way of a back door. The key goal is to eliminate this kind of maneuvering by establishing the necessary trust between Congress and the President." Telephone interview with Stansfield Turner, former DCI (October 7, 1988).

${ }_{180}$ See Gates, The CIA and Foreign Policy, 66 Foreign AfF. 215, 224 (1987-88) (noting that, in the majority of cases, Congress is as well informed about intelligence activities as the Executive).

${ }_{181}$ That is, even beyond the financial controls preventing a paramilitary or similar operation, operations that have a high "noise" quotient are singularly ill-suited for the sliding scale risk system. These are also precisely the types of operations about which Congress would like to have prior notice. Given the violence involved in paramilitary operations, and the requirements of potential operations that require muscular staffing either in the field or in logistics, use of the risk non-disclosure device is sure to be at best merely a temporary reprieve from public knowledge and congressional investigation. Beyond the fiscal control over the contingency fund, the political costs of such a misuse and its inevitable exposure are a powerful incentive for executive cooperation. 
lar to the Boland Amendment. ${ }^{\mathbf{1 8 2}}$ Congressional pressure of this sort should prove to be a proper disincentive for executive abuse of the process.

\section{Modifying the Congressional Oversight Mechanism}

If more flexible statutory language is required, a further step would be to address structural concerns with the present oversight mechanism in Congress. The most important concern is the lack of adequate congressional security. ${ }^{\mathbf{1 6 3}}$ There are domestic ${ }^{\mathbf{1 6 4}}$ and counterintelligence aspects to this issue.

While information leakage is a hot partisan political controversy, it is a minor problem when compared to the problem of foreign infor-

182 Further Continuing Appropriations Act of 1983, Pub. L. No. 97-377, § 793, 96 Stat. 1830,1865 (1982). This is admitting, though, that the whole premise of the risk system-cooperation and compromise-failed.

${ }^{163}$ Congress has historically been a source of information leaks. As far back as the War for Independence, the Continental Congress fired Thomas Paine, the author of Common Sense, after he disclosed details of covert French assistance to the colonies. See IRAN-CONTRA REPORT, supra note 3, at 576. Congress leaked the details of the Jay Treaty between Great Britain and the United States prematurely, despite the presence of a secrecy injunction. See A. SofaER, supra note 97, at 96-97. The Pike Committee leaked a copy of its secret report to the Village Voice in 1976. See L. JoHnson, supra note 8, at 189-91. In 1972, Senator Gravel, without advance notice, read into the Congressional Record excerpts from a top-secret National Security memorandum concerning proposals to mine ports in North Vietnam. See A. MAAss, Congress and THE Common Goon 241 (1983). Congressman Zablocki allegedly personally leaked antiQuaddafi operations to Newsweek. See B. WoodWARD, supra note 6, at 158-60. Former Chairman of the Senate Intelligence Committee David Durenburger publically leaked information about CIA operations in a certain Middle East country. Engelberg, Senator is Quoted As Saying U.S. Recruited Israeli Officer as a Spy, N.Y. Times, Mar. 21, 1987 at A3, col 2. Referring to Senator Durenburger's behavior, House Speaker Jim Wright stated before the House Committee, "I don't have the faintest idea who that would be. I appreciate your keeping his identity secret." Id. Ironically, Wright himself has trouble keeping secrets. He may have doomed effective legislative changes in oversight by provoking criticism and an ethics investigation into his public statements on CIA activity in Nicaragua. See Rasky, Congress: Walking a Tightrope on Intelligence Activities, N.Y. Times, Oct. 11, 1988, at A26, col. 1.

${ }_{104}$ As far as domestic leaking is concerned, it is true that Congress currently has only 2,500 personnel with security clearances, as opposed to 2.2 million in the executive branch and military. See H. Hyde, "Leaks" and Congressional Oversight 4 (on file with the University of Pennsylvania Law Review). It is also true that a Senate Intelligence Committee study stated that journalists listed congressional sources for leaks eight to nine percent of the time, but referred to the administration 66 percent of the time. See id. If the intelligence committee's numbers are accurate, Congress, with only 0.1 percent of total clearances, is responsible for eight to nine percent of national security leaks. See id. These data have led some to make charges of congressional propensity to leak, claiming that "on average, a cleared person in Congress is 60 times more likely than his counterparts elsewhere to engage in unauthorized disclosures." Id. Although reliance on politicized statistics is dangerous, the argument points out the need to become aware of perceived security problems. 
mation gathering. In the order of priority for Soviet KGB activity, the Intelligence and Armed Service Committees of Congress are actually listed higher than the CIA. ${ }^{165}$ As an example of Soviet interest, when the Soviets responded to the overtures of former CIA officer David Barnett, his Soviet control steered him from a CIA position in favor of the Senate Intelligence Committee. ${ }^{166}$

The solution to both leaking and Soviet penetration is to reduce the number of staff who have access to sensitive compartmentalized information ("SCI") and to tighten background checks, including study on how Congress may effectively use polygraphs. ${ }^{167}$ Currently, both committees together include thirty-two members of Congress, four exofficio members, and fifty-eight staff members. ${ }^{168}$ A Joint Intelligence Committee should be established in order to facilitate better security and a more harmonious relationship with the intelligence community. ${ }^{168}$ A Joint Committee would make security easier, reduce the validity of executive branch reluctance to share information with a "leaky" Congress and establish a more coherent congressional approach to intelligence.

Critics of the Joint Committee proposal charge that a Joint Com-

${ }^{165}$ See W. Corson \& R. Crowley, The New KGB: Engine of Soviet Power 357 (1985) (noting that, for the Soviets, Congress is a far more attractive penetration target than the CIA). Congress does not have as stringent screening and vetting procedures, for its employees are not polygraphed. Furthermore, the CIA is highly compartmentalized, unlike the committee structure in Congress. Finally, unless the Soviets have access to the proper decisionmaking level in the CIA, most of the information they gain will be of limited use, compared to what they might get from the Hill. But see Cohen, Congressional Oversight of Covert Activities, 2 INT'L J. INTELligence AND CounTERINTELLIGENCE 155, 161-62 (1988) (Sen. Cohen refuting the idea that the Senate Select Committe on Intelligence has lax security measures).

168 See W. Corson \& R. CROWLeY, supra note 165, at 356 (noting that when Barnett was offered a contract position with the CIA, his assigned case officer, Vladimir Popov, was displeased; Popov proposed and encouraged Barnett to seek a job with either the House or the Senate Intelligence Committee).

${ }_{182}$ There are legitimate rejoinders to the imposition of polygraphs on the Hill. First, polygraphs are useful only when the examination takes into account the institutional values about personnel. There may be significant problems in having a polygraph administered by an agency or personnel unfamiliar with the peculiar congressional ad-hoc personnel, and structural requirements. Furthermore, Congress can rightly point out that while the CIA and NSA regularly "flutter" their personnel, the National Security Council and the State Department, for example, do not. At least one Senator wished to have the Senate Select Committee on Intelligence staff polygraphed. See Hearings, supra note 136, at 216 (statement by Senator Hecht); see also Hyde \& Lungren, Tightening Up the Hill's Loose Lips, Wash. Post, June 2, 1987, at A19, col. 2 (noting that "[n]o members or congressional staff are subject to polygraph either as a screening process or during a leak investigation").

168 See Hyde \& Lungren, supra note 167, at A19.

169 See H.J. Res. 48, 100th Cong., 1st Sess. (1987) (providing for establishment of a Joint Committee on Intelligence); see also TOWER Commission, supra note 9, at V6 (advocating a single congressional oversight committee). 
mittee would be less effective, ${ }^{170}$ and argue that separate staffs would be more likely to achieve a more comprehensive control over information than a unified committee. Why this would be so remains unclear, particularly since separate staffs did not preclude the House Committee's knowledge of the Nicaraguan mining, while the information was not communicated to their Senate colleagues. If the membership of the committee is sufficiently calibrated to ensure senior House and Senate participation, thereby lending institutional prestige, the unified staff should have the necessary clout to effectively oversee the intelligence community. The actual basis for the complaint seems to be narrow institutional interests of the Senate and House, with each chamber reluctant to cede status and other perks. ${ }^{171}$

\section{B. Consolidating Executive Oversight}

Glearly, the Iran-Contra episode revealed flaws in the executive management of the intelligence community. ${ }^{172}$ Within the executive

170 See Boren \& Cohen, Keep Two Intelligence Committees, N.Y. Times, Aug. 17, 1987, at A17, col. 3 (noting that the single Joint Atomic Energy Commission was unable to overcome the problem of leaks).

171 One often voiced concern is that such a committee will become a "captive" of the intelligence agencies it is supposed to oversee. First, if the current practice of limiting terms and revolving memberships continues, it is unclear why this argument would be stronger with a single joint committee than the current arrangement. Secondly, it is not at all clear that a certain degree of "cooption" is necessarily a bad thing. George Pickett, a former budget and program analyst for the SSCI has noted that even some degree of "capture" did not diminish the impact of the intelligence committees. See Pickett, Congress, the Budget and Intelligence, in POLICY AND PROCESs, supra note 1, at $172-73$.

${ }_{172}$ There are two aspects to the collapse of executive oversight in the Iran-Contra initiative. One is a breakdown in already established procedures and the other is the absence of a sufficient oversight mechanism for the entire intelligence community in the executive branch.

Central to the procedural lapses was the failure to adhere to practices regarding "findings." Findings are documents created by the executive branch to justify the execution of a special activity to Congress in order to secure Congressional funding of the operation. See supra notes $44-48$ and accompanying text (detailing how the HughesRyan Amendment created the first requirement for a finding in order to secure congressional funds for covert operations). In the Iran-Contra episode, actions were taken with no findings, post-dated findings, or other procedural irregularities. See IRAN-CoNTRA REPORT, supra note 3, at 378-81 (describing the slipshod nature of Executive finding procedures). It would be a mistake to exaggerate these lapses, however, for "[i]n fact, the committees have received advance notification of every presidential finding but for the two involving the attempted rescue of our hostages in Iran in 1979-80 and the NSC initiative in 1985 and 1986." Covert Hearings, supra note 22, at 176 (statement of David Doherty, General Counsel, CIA).

In response to reports of sloppiness, the President issued a national security directive, ordering that "[n]o special activity may be conducted except under the authority of, and subsequent to, a Finding by the President that such activity is important to the national security of the United States." See National Security Decision Document 
branch, the strongest potential oversight mechanism for the entire intelligence community rests predominantly with the Department of Justice. In the Office of Intelligence Policy and Review, the Counsel for Intelligence Policy is responsible for a variety of activities, ranging from overseeing applications for foreign electronic surveillance (FISA), ${ }^{173}$ monitoring intelligence and counterintelligence activities by executive branch agencies to insure conformity with Department objectives, and participating in the development, implementation and review of intelligence policies, including procedures for the conduct of intelligence and counterintelligence activities. ${ }^{174}$

While the potential for extensive oversight in this office and elsewhere in the Justice Department exists, the department's clout with the intelligence community has varied considerably. Under Garter's Executive Order 12,036, the Attorney General had wide-ranging authority in the realm of intelligence, but since 1981, the influence of that office has diminished. ${ }^{175}$ In fact, even when the attorney general was present during intelligence deliberations, representatives from the intelligence community insisted he was there in his personal-not professional-capacity, and refused to allow his assistants to attend. ${ }^{176}$ This decline should be reversed, since the Executive lacks a broad oversight mechanism that is familiar with law, Congress, and the intelligence community. Intelligence professionals can rightfully mistrust the call for even more lawyers to become involved, but the question is not how many lawyers are involved, but at what level. The recommendation here is to get legal advice at the top that can save operations, careers, and the nation from embarrassment-or worse.

Furthermore, the current President's Intelligence Oversight Board (PIOB), ${ }^{177}$ a three-member panel drawn from outside the govern-

NSDD-286, issued March 31, 1987 (declassified extract on file with the University of Pennsylvania Law Review). The directive also ordered that all findings be made in writing and signed by the President except in extraordinary situations, when the finding would be written as soon as possible. See id. (1982).

${ }^{173}$ See Pub. L. No. 95-511, 92 Stat. 1783 (codified at 50 U.S.G. $\S \S 1801-11$

174 See 28 G.F.R. $§ 0.33$ (1988).

178 See ABA Evaluation, supra note 11, at 15-16.

${ }_{176}$ See Willard, Law and the National Security Decision-making Process in the Reagan Administration, 11 Hous. J. INT'L L. 129, 132 (1988) (noting that other players were permitted subordinates, but that Attorney General Meese was denied both subordinates and recognition that he attended because he was Attorney General). The result of the cumulative restrictions on Department of Justice input on intelligence questions "was to minimize the ability of the Attorney General to participate in the deliberations or to render meaningful legal advice." Id.

${ }^{177}$ See Executive Order Number 12,334, 46 Fed. Reg. 59,955 (1981). The PIOB is distinct from another mechanism, the President's Foreign Intelligence Advisory Board ("PFIAB"). The PFIAB is composed of prominent citizens who serve at the 
ment $^{178}$ and working in the White House, must be strengthened. ${ }^{178}$ The PIOB traditionally has not been influential, lacking the necessary staff, access, and bureaucratic prestige to carry out a sustained oversight mission successfully. ${ }^{180}$ The President has been ill-served by this inefficiency, as demonstrated by the Iran-Contra incident. The PIOB should be strengthened with a permanent legal staff and revitalized with a wider mandate in a successor executive order to Executive Order Number 12,334 . One way to ensure greater prestige and more clout would be to require those serving on the PIOB to do so full-time; Senate confirmation would also serve to raise visibility and enhance clout by placing members' qualifications, intelligence perspectives, and values into the public record.

The consolidation of decisionmaking elites in both houses of Congress into joint committees, the adoption of a sliding scale of notice based upon risk, and more stringent executive procedures for intelligence oversight are all compromises; each branch must make concessions to create a more stable atmosphere for intelligence management and oversight efficiency. These improvements will not eradicate completely the various bases of conflict or charges of abuse. This new regime does, however, move away from the legal fetishism of recent years and places the resolution of oversight problems where it squarely belongs: in the flexible process of political accommodation and compromise.

pleasure of the President. The PFIAB is charged with monitoring the performance, organizations, personnel, collection, or evaluation of intelligence within the intelligence community. In reality, it is highly political. As Martin Anderson has revealed, many of the prominent and busy people selected to the PFIAB do not have time to monitor the intelligence community adequately. When the board does take its oversight mission seriously, it may find itself replaced with a more pliant group. See Anderson, Through the Looking Glass, Common Cause Mag., July-Aug. 1988, at 13, 16. The PFIAB is sadly lacking in power and prestige. See $i d$. Anderson notes that PFIAB chairman Anne Armstrong fought a losing battle for the respect of the major defense figures, such as Casey, Haig, and Schultz. Board members regarded her with "a mixture of toleration and amusement." Id. The important defense figures often delayed their responses to the board, leading to inefficient communication; "recommendations of the board were being implemented slowly, if at all." Id.

${ }_{178}$ See ABA Evaluation, supra note 11, at 17.

178 Reestablished by Exec. Order No. 12,334, supra note 179 , the PIOB is charged with (1) overseeing the legality of intelligence activities, see Miller, Advisory and Oversight Panels on Intelligence Named, N.Y. Times, Oct. 21, 1981, at A27, col. 1 ; (2) "inform[ing] the president of intelligence activities which any member of the board believes are in violation of the Constitution or laws of the United States." ABA Evaluation, supra note 11, at 17; (3) monitoring the performance of the inspectors general and general counsels of the intelligence community; and (4) conducting investigations that it deems necessary and reporting violations to the Attorney General. See id.

${ }^{180}$ See Silver, supra note 5, at 14 (noting that the PIOB consists of part-time members and has virtually no staff). 


\section{GoNCLUSION}

We have an opportunity for a reappraisal of the direction intelligence oversight has taken in the brief decade-and-a-half since its conception. Looking forward, the impulse may be to consider potential structural and statutory changes in response to the immediate historical precedent of the Iran-Gontra incident. Such parochial solutions, however, may fail to establish general oversight conditions applicable in nonaberrant situations. Outside the Iran-Contra incident, the compromise system embedded in the 1980 Oversight Act has worked fairly well. It should be strengthened, not discarded.

The oversight mechanism is not and cannot be a panacea for resolving tensions concerning the proper deployment of intelligence assets in support of American foreign policy. Neither analysis of constitutional text, resort to decisional authority, nor the citing of historical precedent will help draft statutes that will resolve the fundamental policy differences that have historically confounded the process. Policy compromise must be accomplished in traditional open fora of political debate. A new approach can expedite the political process by removing the need to resort to legal formalism, a device previously used to achieve policy preferences unobtainable by other means.

The nation needs an effective intelligence capability. The United States has global commitments and challenges that require unprecedented flexibility and efficient integration of all resources. An effective intelligence capability is central to America's success in fulfilling its geopolitical responsibilities and maintaining its security. The United States cannot walk away from this reality without assuming grave risks. As one statesman said to another republic over 2,400 years ago, "It may have been wrong to take [the empire]; it is certainly dangerous to let it go."181

181 Thucydides, The Peloponnesian War 161 (R. Warner trans. 1954) (quoting Pericles). 
